\title{
How Does Value Creation Manifest Itself in the Nexus of Sport and Business? A Systematic Literature Review
}

\author{
Harri Jalonen1*, Sasu Tuominen², Arto Ryömä ${ }^{3}$, Jaakko Haltia1, Juho Nenonen², Anna Kuikka² \\ ${ }^{1}$ Turku University of Applied Sciences, Turku, Finland \\ ${ }^{2}$ University of Eastern Finland, Joensuu, Finland \\ ${ }^{3}$ University of Turku, Turku, Finland \\ Email: *harri.jalonen@turkuamk.fi
}

How to cite this paper: Jalonen, $\mathrm{H}$., Tuominen, S., Ryömä, A., Haltia, J., Nenonen, J. and Kuikka, A. (2018) How Does Value Creation Manifest Itself in the Nexus of Sport and Business? A Systematic Literature Review. Open Journal of Business and Management, 6, 103-138.

https://doi.org/10.4236/ojbm.2018.61008

Received: December 8, 2017

Accepted: January 20, 2018

Published: January 24, 2018

Copyright $(9) 2018$ by authors and Scientific Research Publishing Inc. This work is licensed under the Creative Commons Attribution International License (CC BY 4.0).

http://creativecommons.org/licenses/by/4.0/

\begin{abstract}
Sport is a widely used as a vehicle for promoting business. Global brands invest tens of millions of euros in high performance athletes, top teams, and popular sporting events. Studies have also shown the potentiality of sport in the business context. However, relatively few studies have focused on the interaction of business and sport from a value-creation perspective. Knowledge focusing on value creation within and through sport is scattered throughout literature and a systematic understanding of how value creation manifests itself in a business context is lacking. Using a systematic literature review and inductive analysis of 44 empirical studies, the article presents six identified topics that represent the various angles to value creation in the nexus between sport and business. The topics are 1) the many shades of value, 2) brands and sponsorship as value-creators, 3) the value of CSR in and through sport, 4) sport as a network and platform, 5) sport for developing organisations internally, and 6) value congruence and identification. The article contributes to both business management and sports management. The article proposes theoretical and managerial implications and identifies avenues for further research.
\end{abstract}

\section{Keywords}

Value Creation, Management, Sports Management, Brand, Sponsorship, CSR

\section{Introduction}

Roger Federer (tennis), LeBron James (basketball), and Cristiano Ronaldo (soccer) were the three most valuable athletes in terms of endorsements 2017. Each 
of them earned more than 30 million US dollars from sponsorship contracts [1]. At same time, the English Premier League announced that it has earned over 5.1 billion pounds for selling the television rights to the 2016/17, 2017/18, and 2018/19 seasons [2]. These, and numerous other examples of money spent on sport reflect a strong conviction that sport is useful vehicle for promoting business. Academic literature has also confirmed this claim. Research on the topic has shown that sponsorship announcements can have a positive effect on a firm's share price [3] [4] [5] and sponsorship also has an impact on the different antecedents of brand equity, such as corporate image, brand image, brand awareness, and brand personality [6]. Thus, it is not surprising that brands and firms all over the world invest big amounts of money in high performance athletes, top teams, and popular sporting events. Global sponsorship revenue has almost doubled within the last ten years from 37.9 (2007) to 60.2 (2016) billion dollars [7]. By investing in sponsorship, firms either expect direct business benefits such as increased brand equity and sales or they indirectly use sport as a platform to demonstrate their involvement in corporate social responsibility (CSR) [8] [9].

Although many studies have shown the potential of sport in a business context [10], relatively few studies have focused on the interaction of business and sport from a value-creation perspective. Value creation has been touched upon in functionally oriented studies which have shown that sport can bring value, amongst other things, to management [11] [12], consumer marketing [13] [14], and communicating corporate social responsibility [15] [16]. However, these studies have not shed any light on the value-creation process itself. To further elaborate, if studies have focused on value creation between sport and business, they have examined the value exchange between parts, not as a co-created process, where the parts form a kind of joint agency. Although some studies have adopted the value-creation approach in a sports context [17], they are mainly focused on the collaboration between sport and fans-not between sport and business. What is particularly lacking is an extensive synthesis of the complexity of value co-creation in the nexus of sport and business.

What seems quite clear, however, is that sport's value cannot be measured solely by monetary metrics. Many studies have shown that sport inspires people at an emotional and symbolic level [18] [19]. Adapting a pluralistic view of value [20], this study accepts that value can be hidden in various places and take different forms. Using a systematic review of the literature, we aim to answer following research question: how does value creation manifest itself in the nexus of sport and business?

We adopt the view that "value" is the perceived utility derived from the use of the value proposition (e.g. branding through top athletes). "Value creation" does not happen in isolation, but is created when the value beneficiary accepts the value propositions offered by the value provider (e.g. firms' PR activities at sporting events). By "nexus" we refer to the institutionalised practices (e.g. 
sponsorship deals) and informal interplay (e.g. spontaneous fan behaviour) embedded in the network of actors (individuals and organisations). Using the actor-to-actor (A2A) approach, we disassociate actors from the predesigned roles of consumers as value beneficiaries and firms as value providers [21]. Instead of fixed roles, we adopt the view that "all actors fundamentally do the same things: integrate resources and engage in [...] exchange, all in the process of co-creating value" ([21], p. 7).

While sports management is a hybrid discipline [22], for-profit and notfor-profit sports organisations and firms share a common interest in value creation [23]. In other words, in conjunction with the focus placed on the sporting activities themselves, directors of non-profit sports organisations are as deeply concerned about their financial future as their business colleagues are. Therefore, the predesigned roles of value provider and beneficiary in the area of sport and business are blurred in this study. Instead, we focus on the nexus where multiple forms of value are co-created. However, in order to contribute to management research by studying the value co-creation process, we believe it useful to consider some typical (albeit particular) features of sport, such as emotional experiences, the irrational passions of fans, high-level brand loyalty, vicarious identification, on-field winning over profit, and the variable quality of "sports products" [24] [25]. We expect that, due to these features, the nexus under investigation will provide its own particularities, and therefore it will be useful to explore value creation in the context of the sport-business nexus, rather that approach business and sport separately. That is to say, including sport in the nexus allows us to utilise, for example, the emotional value creation process differently than when sport is excluded. Therefore, we argue that by uncovering aspects hitherto hidden in earlier studies on the nexus between sport and business, we can extend the prevailing knowledge on value co-creation in management literature [26] [27] in the nexus of different fields. By understanding "management" as all aspects of business studies, including, amongst other things, management, marketing, and finance [22], we will provide a synthesis of studies that touch upon the issues of value creation through the nexus of sport and business.

As our review also focuses on the sports context, it can also be used to advance sports-management research in at least in two ways. Firstly, as Chalip [22] and Costa [28] have stressed, in order to develop as a serious field of research, sports management studies must follow a sophisticated and rigorous research design. A systematic review and analysis of the existing literature fulfils this need. A systematic review and analysis are necessary for building sports-management theory. Secondly, due to the characteristics of the field, sports-management research should adopt a cross- and multidisciplinary perspective [22] [28] [29]. By applying a pluralistic view of value creation to various aspects of sports management, such as branding, corporate social responsibility, and networking, the review is not limited to specific disciplines, but takes a cross- and multidisciplinary approach. 
By performing a systematic literature review [30] [31] this study integrates existing information and provides a new understanding of the various aspects of value creation in the nexus of sport and business. Instead of focusing on one theoretical framework, we use several theoretical approaches. In so doing, we believe that the review will provide insight into the complexity of value co-creation in the nexus of sport and business. We also present and discuss practical implications, which we believe will be useful for firms considering how they might exploit sport to develop their business. In addition, the review provides insights into sports organisations that they can then use to create tempting value propositions for firms.

This article is organised as follows. In Section 2, the theoretical backgrounds are described. We use several theoretical approaches. Section 3 presents the methods and research design used. In Section 4, the results of the systematic literature review are presented. Finally, in Section 5, the results are discussed and conclusions (both theoretical and managerial) are drawn, with suggestions for avenues for further research.

\section{Theoretical Background for Value Creation in the Nexus of Sport and Business}

Several theoretical perspectives on value creation have been introduced in management literature since the 1930s. Theories on transaction costs (Ronald Coase), innovation (Joseph Schumpeter), the value chain (Michael Porter), as well as the resource-based view of firms (Edith Penrose) are all very much based on the assumption that the development of external value (especially customer value) is largely based on a company's internal resources and capabilities in value creation [32]. In addition, the social capital theory and the network approach have been offered as complementary sources for value-creation. According to these views, a firm's value is created in long-term relationships between buyer and supplier, as well as other partners, by acquiring the firm's external resources to produce competitive products and services within the markets [33]. In the network approach, social exchange plays a major role in and between economic transactions [34].

However, more recently, a new and even more relational approach to value creation has been offered, especially in marketing literature. Referring to the service-dominant logic, value creation in the 21 st century occurs in dynamic exchange relationships [26]. Co-creation is fundamentally embedded as part of the value concept in service-dominant logic. Conceptually, co-creation may be understood as a general approach covering all specific occasions in which firms and customers generate value through interaction [35]. According to this approach, value is created in the processes between supplier and customer [36]. Besides co-creation, resource integration and network approaches are also essentially embedded in service-dominant logic. Unlike the traditional value-chain approach, in service-dominant logic, all essential actors (or economic entities) pro- 
vide resources in exchange processes in which the value is co-created between each partner [26]. Accordingly, value is created in exchange processes in which different partners interact with others, both as value-creators and value-beneficiaries, without an explicit division between customers and providers [35]. Value co-creation has been widely adopted, especially in service and marketing literature but also in innovation and technology management, including business-to-business as well as to business-to-customer settings [27].

In the literature, sport has been described as a social context that connects different actors through the exchange of resources and participation [37]. Both "in sports" and "through sports" perspectives are necessarily involved in the management and sports management literature. By "in sports", we are often referring to the management and marketing of a sports team or other sporting entity, whereas Shilbury et al. [38] present "through sports" rather as a firm's perspective on value-creation. According to this view, sport serves as a platform on which to achieve different business-related goals, such as brand awareness or increased sales by advertising or branding through sports [39]. However, in the earlier research these two views are often kept separate and they are also restricted to the limited amount of actors in touch with the sports entity or firm. Contrary to this, in the current study we explore the relational aspects of value creation (such as networks and service-dominant logic) and demonstrate how value creation occurs in the complex context of sports. Thus sport is considered as a platform that connects different actors as well as different perspectives (in and through sports).

Sport as a particular field with particular features allows the sports-business nexus certain qualities that make the co-creation nexus worthwhile examining and including in management literature. Moreover, it is also assumed in this study that value creation may take several different forms. The literature suggests several approaches to value. Sheth et al. [40], for example, have introduced the five values that influence consumer behaviour as follows: functional value as "the perceived utility acquired from an alternative's capacity for functional, utilitarian, or physical performance" ([40], p. 160), social value as "the perceived utility acquired from an alternative's association with one or more specific social groups" ([40], p. 161), emotional value as "the perceived utility acquired from an alternative's capacity to arouse feelings or affective states" ([40], p. 161), epistemic value as "the perceived utility acquired from an alternative's capacity to arouse curiosity, provide novelty, and/or satisfy a desire for knowledge" ([40], p. 162 ), and conditional value as "the perceived utility acquired by an alternative as the result of a specific situation or set of circumstances facing the choice maker" ([40], p. 162). Rintamäki et al. [41] have addressed value from the provider's perspective. According to them, a customer value proposition can be based on economic value (focus on price), functional value (focus on solutions), emotional value (focus on customer experience), and symbolic value (focus on meanings). The above-mentioned categorisations are used as interpretative frames to explore value in the nexus of sport and business. 
We assume that one single form of value doesn't necessarily provide value alone but the development of value requires interaction between different actors as well as different sources of value. The literature has demonstrated the relevance of relational and inter-active processes in value creation. Accordingly, the development of a firm's economic value might be dependent on functional, emotional, or symbolic forms of value. This interaction might take place inside the organisation or between different organisations as well as between the organisation and its customers (or other constituents). For example, the different components of functional value enhance the economic value of a firm. Research has shown that lower turnover enhances the effectiveness and productivity of a firm, which in turn affects a firm's financial performance [42]. However, from a company perspective, it is often a prerequisite that external constituents experience the symbolic or emotional value that, in turn, enables the development of a functional or economic value for a firm. As an example of this, research on consumer behaviour has attached the customer's emotional value, as well as their re-purchase behaviour, essentially to satisfaction and loyalty [43]. Also, customer-based brand equity has been shown to affect firms' financial performance [44].

In accordance with this, we aim to explore the different sources of value as well as the possible interaction of values especially in the context of the sports-business nexus. It is supposed that value-creation may also take several forms in the context of this study. It is also presumed that interaction as well as co-creation are essential elements in the value creation process between different actors who participate in sport in their various roles. Even though value-creation is approached in this study particularly from a business perspective, it must be noted that other actors also have a key role in the analysis, due to the co-creative and interactive nature of value creation in and through sports.

\section{Research Design and Methods}

In this study, sport is understood in all its forms (commercial, amateur, and non-profit). In our understanding, the value potential of a sports organisation cannot be exhaustively defined by the form of the sports organisation. As an illustrative example, there are numerous non-profit sports organisations that have a turnover of billions of euros. Instead focusing on the differences between sports organisations, we emphasise the similarities between them. Emotional experiences, uncertainty of outcome, vicarious identification, the passions of fans, and the variable quality of sports products [25], amongst other elements, are seen in this study as characteristics that unite, not divide, commercial, amateur, and non-profit sports organisations. These are also characteristics that create useful opportunities for companies.

This study undertook a systematic review of the literature. A systematic literature review is a method that helps by "making sense of large bodies of information" and enables the uncovering of "areas where spurious certainty abounds" 
[31]. As a research approach, the systematic literature review was better known in medical sciences but was later adapted to include social sciences as well as management studies. For example, Trandfield et al. [30] argue for the evidence-based approach that a systematic literature review can provide for management studies by synthesising research as well as accumulating knowledge for both theoretical and practical purposes. Also worth noting is that a systematic review helps to overcome the biases that are inherent in single studies [31]. In order to realise its potential, a systematic review should be performed rigorously and transparently.

The literature review was conducted in four consecutive phases. In the first phase, the selection criteria were discussed and decided upon by six researchers who worked for the Business Value from Sport project. Based on the authors' experiences of the field and a preliminary review of the literature, the following inclusion criteria were decided. Firstly, an article had to be an empirical study focusing on value creation in the nexus between sport and business. There were no restrictions on types of value (e.g. economic, functional, symbolic, emotional, social; see Sheth et al. [40] and Rintamäki et al. [41] or perspectives on value (brand, firm, sport organisation/product, customer, network, society). Secondly, a Boolean search phrase "sport" AND "value" AND ("business" OR "management" OR "leadership" OR "brand" OR "CSR") had to be matched with the abstract of the article. Thirdly, an article had to be published in a peer-reviewed scientific journal. Fourthly, only studies written in English with full text access were considered. Based on the above-mentioned parameters, a computerised search was carried out in the following databases: ABI Inform ProQuest, Academic Search Elite (EBSCO), Elsevier Science Direct, and Emerald. The four databases contain key journals in the fields of business, management, organisations, and sports management. The search yielded 253 articles of which 20 were duplicates and were, therefore, discarded.

In the second phase, the abstracts of 233 articles were read cursorily and individually by six researchers. Short notes on the articles were written and discussed in a workshop organised by the researchers. Roughly half of the articles were classified as inappropriate at this stage in terms of the research question. An examination of the abstracts reduced the number of articles to 125. Purely conceptual and theoretical articles were discarded in this phase.

In the third phase, the 125 articles were read in full by the six researchers. 20 22 articles were read individually by each of the researchers. The objective of this phase was to ensure that the studies were relevant to the purpose of this article and to increase understanding of the various manifestations of value and the myriad forms of value creation in the nexus between sport and business. The reading revealed that many of the articles found in the first and second phases included references to articles which did not meet all of the inclusion criteria. All of these potentially important articles were read carefully. If the article was judged to be relevant, it was included in the review process. It was also found that the majority of articles that were first selected on the basis of the abstracts 
were not relevant to the research question. 89 articles were discarded. The majority of discarded articles were either those that only mentioned "value" without any further discussion or those in which sport was merely an illustrative example of the value creation context. Limiting the searches to four databases prevented the discovery of articles that were not listed in these databases. In order to avoid the problem described by Greenhalgh and Peacock [45], that is "a systematic review of complex evidence cannot rely solely on predefined, protocol driven search strategies, no matter how many databases are searched", a complementary search source for the literature was undertaken. The complementary search yielded 8 studies that addressed value creation through sponsorship lenses. The total number of articles under review for this study was 44 . All 44 articles were analysed in terms of their key findings, their theoretical framework, their methodology, their managerial implications and, in particular, the various value types and their interactions. The analysis of every article was based on an independent interpretation by two researchers. Problematic studies were discussed and a consensus was reached rather easily.

The fourth phase consisted of reducing and combining the various forms of value creation in the nexus of sport and business. Adapting the grounded theory approach [46] and inductive reasoning, several combining and restructuring cycles were undertaken with the help of mind mapping and earlier classifications found in the reviewed literature. We finally identified six emerging topics that represented different angles to value creation in the nexus of sport and business.

Although a systematic literature review is a rigorous method "to reduce bias in the selection and inclusion of studies, to appraise the quality of the included studies, and to summarize them objectively" [31], reviewers face many difficulties during the process. It has been noted, for example, that reviewers succumb to the temptation of including a restricted search for relevant studies and an inappropriate combination of studies [31]. Despite using the inclusion criteria and expanding the search process beyond four databases, it is highly probable that other studies exist which some other researcher may have included in his/her review. This could not be avoided because the data extraction described above required interpretation which, in turn, depended on the prior experience of the researchers involved. However, it should be emphasised that we took these challenges into consideration and created a collaborative process in which we discussed borderline cases amongst the six researchers. We believe that this procedure significantly improved the search, selection, and analysis processes and reduced the threat of systematic errors.

\section{Results: Value Creation in the Nexus of Sport and Business}

During the collaborative process and using the grounded theory approach [46], we identified six topics that represent different angles to value creation in the nexus of sport and business. The topics are 1) the many shades of value, 2) brands and sponsorship as value creators, 3) the value of CSR in and through sport, 4) sport as a network and platform, 5) sport for developing organisations 
internally, and 6) value congruence and identification. Numbers 1 - 6 refer to the topic identified in the article. Topics were represented in the material as follows: topic 1 (15 articles), topic 2 (15 articles), topic 3 ( 8 articles), topic 4 (6 articles), topic 5 (5 articles), topic 6 (9 articles).

The six identified topics are discussed in detail in the following subsections. Before that, a short overview of the studies included in the review is presented in Table 1.

\subsection{Many Shades of Value}

Value has been a focal concept in economics and an eternal question in philosophy. However, consensus on its content is nowhere in sight. Value can take different forms that cannot be sorted into an unambiguous order. Quite the contrary, it is known that values are incommensurable in the sense that there is no true general overall ranking of the realisation of one value against the realisation of another value [47]. The incommensurability of values arises from the plurality of interests and judgments [20].

The incommensurability and the pluralism of values emerged from the reviewed literature. The reviewed literature revealed five manifestations of value in the nexus between sport and business: economic, functional, symbolic, emotion$\mathrm{al}$, and social values. Economic value manifested itself as the difference between returns and costs. Studies show that investing in sport sponsorship (sports events, teams, or individual athletes) may have a positive influence on companies' share prices [5] [48], brand equity [49], and sales [50]. Functional value was identified as the development of a company's behaviour through sport. Sport has been used as a vehicle for improving a company's performance and leadership culture [11] [12] or showing its commitment to the community it operates in [15] [16]. Symbolic value manifested itself in expressions of togetherness or distinctiveness. Sports fans have their own rituals and traditions which foster the feeling of being part of a larger something. The reviewed studies show that firms benefit if they are able to create offerings that are aligned with that "larger something" [51] [52] [53]. Sport is also a context in which one can show intense emotions. Sports fans are rather irrationally committed to their favourite teams and athletes. An emotional and irrational reaction to sport is a double-edged sword that helps brand building but can also destroy it. Studies show that emotional value is realised in the situations in which the brand is not interpreted as an intruder but as a participant that enables the team's or athlete's success [19] [54]. In addition to the economic, functional, symbolic, and emotional use of sport in value creation, the reviewed literature also shows that sport has been used more broadly for developing communities. The social value of sport is realised in the form of the wellbeing of communities that surround it by enhancing the economic life of the region or increasing social capital [55].

Instead of there being separate and clear-cut categories of value, the reviewed studies point out that various forms of value are often interconnected and 
Table 1. Overview of relevant research on value creation in the nexus of sport and business.

\begin{tabular}{|c|c|c|c|c|c|c|}
\hline Author(s) & $\begin{array}{l}\text { Key finding(s): How is value } \\
\text { manifested? }\end{array}$ & $\begin{array}{l}\text { Methodology } \\
\text { Data/sample }\end{array}$ & $\begin{array}{l}\text { Type of } \\
\text { value }\end{array}$ & Interaction of values & $\begin{array}{l}\text { Perspective } \\
\text { on values }\end{array}$ & $\begin{array}{c}\text { Topic(s) } \\
(1-6)\end{array}$ \\
\hline $\begin{array}{c}\text { Abosag et al. } 2012 \\
{[54]}\end{array}$ & $\begin{array}{l}\text { Fans that have a strong emotional } \\
\text { attachment to their club have a } \\
\text { stronger perception of the club as a } \\
\text { brand and support brand extension. }\end{array}$ & $\begin{array}{l}\text { Survey ( } 842 \\
\text { football } \\
\text { supporters) }\end{array}$ & $\begin{array}{l}\text { Emotional } \\
\text { Economic }\end{array}$ & $\begin{array}{l}\text { Transform: from } \\
\text { emotional to economic } \\
\text { value. }\end{array}$ & $\begin{array}{c}\text { Brand } \\
\text { Customer } \\
\text { Sports product }\end{array}$ & 1,2 \\
\hline $\begin{array}{l}\text { Anagnostopoulos } \\
\text { et al. } 2013 \text { [68] }\end{array}$ & $\begin{array}{l}\text { Football clubs will create new } \\
\text { generations through CSR. }\end{array}$ & $\begin{array}{l}\text { Interviews ( } 21 \\
\text { charitable } \\
\text { foundation } \\
\text { managers) }\end{array}$ & $\begin{array}{l}\text { Emotional } \\
\text { Functional } \\
\text { Economic }\end{array}$ & $\begin{array}{l}\text { Transform: from } \\
\text { emotional to functional } \\
\text { and economic } \\
\text { (stakeholders' values). }\end{array}$ & $\begin{array}{l}\text { Society } \\
\text { Sports product } \\
\text { Brand }\end{array}$ & 3 \\
\hline $\begin{array}{l}\text { Bauer et al. } 2005 \\
\quad[57]\end{array}$ & $\begin{array}{l}\text { A customer-based brand equity } \\
\text { model is developed in a team sport } \\
\text { context. Results of the study also } \\
\text { show that brand equity and especially } \\
\text { brand awareness are positively related } \\
\text { to the number of spectators. }\end{array}$ & $\begin{array}{c}\text { Survey } \\
\text { (1594 sport fans) }\end{array}$ & $\begin{array}{l}\text { Emotional } \\
\text { Symbolic } \\
\text { Functional } \\
\text { Economic }\end{array}$ & $\begin{array}{l}\text { Transform: from emo- } \\
\text { tional and symbolic to } \\
\text { functional and economic } \\
\text { values. }\end{array}$ & $\begin{array}{l}\text { Sports product } \\
\text { Brand }\end{array}$ & 2 \\
\hline $\begin{array}{l}\text { Benijts et al. } 2011 \\
\quad[89]\end{array}$ & $\begin{array}{l}\text { Coopetition in sports leagues is } \\
\text { crucial in the value creation process. }\end{array}$ & $\begin{array}{l}\text { Interviews } \\
\text { (27 managers of } \\
\text { cycling teams) }\end{array}$ & $\begin{array}{l}\text { Functional } \\
\text { Symbolic }\end{array}$ & $\begin{array}{l}\text { Platform: economic value } \\
\text { will develop in networks. }\end{array}$ & Sports product & 4 \\
\hline $\begin{array}{l}\text { Blumrodt et al. } \\
\quad 2013 \text { [69] }\end{array}$ & $\begin{array}{l}\text { CSR in the sports organisation } \\
\text { increases fans' commitment to the } \\
\text { club. }\end{array}$ & $\begin{array}{l}\text { Structured } \\
\text { questionnaire } \\
\text { (996 football } \\
\text { supporters) }\end{array}$ & $\begin{array}{l}\text { Emotional } \\
\text { Functional } \\
\text { Economic }\end{array}$ & $\begin{array}{l}\text { Transform: from } \\
\text { emotional to economic } \\
\text { and functional value. }\end{array}$ & $\begin{array}{l}\text { Sports product } \\
\text { Society Brand }\end{array}$ & 3 \\
\hline $\begin{array}{l}\text { Blumrodt et al. } \\
\quad 2012[132]\end{array}$ & $\begin{array}{l}\text { Activity in the community has the } \\
\text { brand value of the football club. }\end{array}$ & $\begin{array}{l}\text { Structured } \\
\text { questionnaire } \\
\text { (996 football } \\
\text { supporters) }\end{array}$ & $\begin{array}{l}\text { Emotional } \\
\text { Functional } \\
\text { Economic }\end{array}$ & $\begin{array}{l}\text { Transform: from } \\
\text { emotional to economic } \\
\text { and functional value. }\end{array}$ & $\begin{array}{l}\text { Sports product } \\
\text { Brand }\end{array}$ & 3 \\
\hline $\begin{array}{c}\text { Burnes and } \\
\text { O’Donnell } 2011 \\
{[11]}\end{array}$ & $\begin{array}{c}\text { Sport offers a context in which } \\
\text { business leaders can learn lessons, } \\
\text { especially in terms of change and } \\
\text { staff development. }\end{array}$ & $\begin{array}{l}\text { Interviews } \\
\text { (8 leading } \\
\text { coaches) }\end{array}$ & $\begin{array}{l}\text { Functional } \\
\text { Emotional }\end{array}$ & $\begin{array}{l}\text { Transform: from } \\
\text { emotional functional } \\
\text { value. }\end{array}$ & Firm & 1,5 \\
\hline $\begin{array}{l}\text { Brauns- } \\
\text { tein-Minkove } \\
\text { et al. } 2011[63]\end{array}$ & $\begin{array}{l}\text { The study develops a model that can } \\
\text { be used to analyse the effectiveness of } \\
\text { an athlete's endorsers for non-sports } \\
\text { products. The results revealed five } \\
\text { elements: athlete identification, sport } \\
\text { identification, match-up, perceived } \\
\text { value, purchase intention }\end{array}$ & $\begin{array}{l}\text { Structured } \\
\text { questionnaire } \\
\text { (400 university } \\
\text { students) }\end{array}$ & $\begin{array}{l}\text { Emotional } \\
\text { Economic }\end{array}$ & $\begin{array}{l}\text { Transform: from } \\
\text { emotional (finding athlete } \\
\text { endorsers that suit the } \\
\text { brand and raise positive } \\
\text { emotions) to economic } \\
\text { value. }\end{array}$ & Brand & 2,6 \\
\hline $\begin{array}{c}\text { Carrillat and } \\
\text { d'Astous } 2012 \\
{[62]}\end{array}$ & $\begin{array}{l}\text { The results of the study clude that it } \\
\text { is more beneficial for companies to } \\
\text { choose to be the official sponsor of an } \\
\text { event or the official provider of } \\
\text { integrated products in the event. } \\
\text { Trying to concentrate on both } \\
\text { strategies is ineffective. }\end{array}$ & $\begin{array}{l}\text { Experimental } \\
\text { design (149 } \\
\text { university } \\
\text { students) }\end{array}$ & $\begin{array}{l}\text { Emotional } \\
\text { Functional }\end{array}$ & $\begin{array}{l}\text { Transform: from } \\
\text { emotional to functional } \\
\text { (positive consumer } \\
\text { attitudes to sponsorship } \\
\text { effectiveness). }\end{array}$ & Brand & 2 \\
\hline $\begin{array}{c}\text { Carlson et al. } 2009 \\
{[97]}\end{array}$ & $\begin{array}{l}\text { When a consumer identifies with the } \\
\text { team, it has positive effects on retail } \\
\text { spending and viewership increases. }\end{array}$ & $\begin{array}{l}\text { Survey (162 } \\
\text { university } \\
\text { students) }\end{array}$ & $\begin{array}{l}\text { Emotional } \\
\text { Symbolic } \\
\text { Economic }\end{array}$ & $\begin{array}{l}\text { Transform: from } \\
\text { emotional and symbolic } \\
\text { to economic (increase in } \\
\text { spending due to } \\
\text { identification). }\end{array}$ & Brand & 2,6 \\
\hline
\end{tabular}




\section{Continued}

\begin{tabular}{|c|c|}
\hline $\begin{array}{c}\text { Clark et al. } 2009 \\
{[48]}\end{array}$ & $\begin{array}{c}\text { Title sport sponsorship appears to } \\
\text { trade largely at market-clearing } \\
\text { prices. }\end{array}$ \\
\hline $\begin{array}{c}\text { Close and Lacey } \\
2013[100]\end{array}$ & $\begin{array}{l}\text { The event-sponsor fit is crucial for } \\
\text { value creation - consumers' positive } \\
\text { perceptions of the sponsor rise when } \\
\text { they perceive a greater fit with the } \\
\text { event; yet, congruity does not } \\
\text { influence consumers' attitudes } \\
\text { towards the event. }\end{array}$ \\
\hline Cortsen 2013 [19] & $\begin{array}{l}\text { The "hybrid" nature of the sports } \\
\text { brand draws highly on "emotional } \\
\text { capital" and "social currency". } \\
\text { Personal sports branding acts as a } \\
\text { "hybrid", which facilitates "hybrid" } \\
\text { branding relationships between } \\
\text { personal sports brands and sports } \\
\text { brands at the product and } \\
\text { corporate levels. }\end{array}$ \\
\hline
\end{tabular}

Crader and sponsorship can be successfully Santomier 2011 used to facilitate the development and

DeSarbo and Madrigal 2011 implementation of a new organisational structure.

$$
\begin{aligned}
& \text { The study explores the } \\
& \text { multidimensional aspects and } \\
& \text { heterogeneity of fan avidity. }
\end{aligned}
$$

Young adult consumers' emotional attachment to sports celebrities can

\section{The event-time \\ methodology}

(114 sport events)

Economic

Platform: sport enables

value creation in terms of

share prices

Survey (1615 Emotional

cycling race Functional

spectators) Symbolic

Interviews (with a Emotional sports celebrity Functional and her manager) Economic

\section{A case-study} analysis

\section{Survey (307 student \\ sport fans)}

Survey

(207 university students)

Survey (553 sports event attendees)

Documentary research method
Dix et al. 2010 be used by firms in order to influence customers' buying intentions and strengthen their brand loyalty.

Sport sponsorship provides an

Donlan 2014 [49] appropriate vehicle through which to build consumer-based brand equity.

Filizöz and Fisne 2011 [73]

Gwinner and Bennett 2008 [60]

Emotional Symbolic Economic

Economic

Functional Symbolic

The study reveals the gaps in sponsorship relationships that are changing perceptions of value, opportunity, and responsibility. It is concluded that sponsor partners

Farrelly 2010 [67] should have explicit roles in the value-creation process. Also a higher level of commitment and effort is demanded in developing marketing capabilities in sponsorship relationships.

The fit between the sponsor and the sponsored sports event has a positive influence on consumers' purchase intensions.
Interviews (24 sports \& business managers)
Functional Economic
Survey (552 sports event attendees)
Emotional

Functional Economic
Platform: the event facilitates the value creation process for fans Sponsorship 2,6

\section{Transfer. emotions} attached to a sporting Sports product celebrity transfer to the sponsor's brand.
Brand Firm 1

Platform: sport offers a benchmark for developing

Firm organisations internally.

\section{Transform: from} emotional and symbolic value to functional value.

Customer

\section{Transform: from} emotional and symbolic to economic value.

\section{Platform: sport enables} value creation for sponsoring brands.

Transform: from symbolic to functional value.

Transform: from functional (successful sponsorship relationship)

to economic value. Platform: sport enables value creation for joint partners.
Business relationships

\section{Transform: from} emotional value to functional and economic value.
Brand 


\section{Continued}

\begin{tabular}{|c|c|c|c|c|c|c|}
\hline $\begin{array}{l}\text { Hedlund } 2014 \\
\text { [99] }\end{array}$ & $\begin{array}{l}\text { A feeling of membership in the sport } \\
\text { fan consumption community and } \\
\text { participation in the rituals and } \\
\text { traditions associated with the } \\
\text { community lead to increases in future } \\
\text { intentions to attend the team's games, } \\
\text { purchase the team's merchandise, } \\
\text { and recommend the team's } \\
\text { games to others. }\end{array}$ & $\begin{array}{l}\text { Survey (627 } \\
\text { university } \\
\text { students \& } \\
\text { alumni) }\end{array}$ & $\begin{array}{l}\text { Economic } \\
\text { Functional } \\
\text { Emotional } \\
\text { Symbolic }\end{array}$ & $\begin{array}{l}\text { Transfer. emotional } \\
\text { attachment to the team } \\
\text { and community facilitate } \\
\text { economic outcomes } \\
\text { through fan behaviour. }\end{array}$ & $\begin{array}{l}\text { Customer } \\
\text { Firm }\end{array}$ & 2,6 \\
\hline $\begin{array}{l}\text { Herrmann et al. } \\
\quad 2014 \text { [61] }\end{array}$ & $\begin{array}{l}\text { Well-known brands may have several } \\
\text { advantages in sports sponsorship. } \\
\text { Spectators (consumers) tend to take } \\
\text { well-known brands into a } \\
\text { considerations set with and even } \\
\text { without the explicit memory that the } \\
\text { brand is the sponsor. }\end{array}$ & $\begin{array}{l}\text { Survey (1084 } \\
\text { sports event } \\
\text { attendees) }\end{array}$ & $\begin{array}{l}\text { Functional } \\
\text { Economic }\end{array}$ & $\begin{array}{l}\text { Platform: sport enables } \\
\text { value creation for } \\
\text { sponsoring brands. }\end{array}$ & Brand & 2 \\
\hline $\begin{array}{l}\text { Hu et al. } 2012 \\
{[133]}\end{array}$ & $\begin{array}{l}\text { Irresponsible behaviour will harm the } \\
\text { sports brand. The brand is not only } \\
\text { affected by sporting performance }\end{array}$ & $\begin{array}{l}\text { Survey } \\
\text { (220 university } \\
\text { students) }\end{array}$ & $\begin{array}{l}\text { Emotional } \\
\text { Symbolic } \\
\text { Functional }\end{array}$ & $\begin{array}{l}\text { Transform: from } \\
\text { emotional and symbolic } \\
\text { to functional value. }\end{array}$ & $\begin{array}{c}\text { Society } \\
\text { Sports product }\end{array}$ & 3 \\
\hline $\begin{array}{c}\text { Inoue et al. } 2013 \\
{[75]}\end{array}$ & $\begin{array}{l}\text { It is profitable for non-profit } \\
\text { organisations to co-operate with } \\
\text { strong professional sports } \\
\text { organisations. }\end{array}$ & $\begin{array}{l}\text { Survey } \\
\text { (2809 sports } \\
\text { newsletter } \\
\text { subscribers) }\end{array}$ & $\begin{array}{l}\text { Economic } \\
\text { Emotional } \\
\text { Symbolic }\end{array}$ & $\begin{array}{l}\text { Transform: from symbolic } \\
\text { and emotional to } \\
\text { economic value. }\end{array}$ & $\begin{array}{l}\text { Customer } \\
\text { Consumer } \\
\text { Firm Brand } \\
\text { Sports product }\end{array}$ & 3 \\
\hline $\begin{array}{c}\text { Kerwin and Bopp } \\
2014 \text { [95] }\end{array}$ & $\begin{array}{l}\text { Due to high personnel (player) } \\
\text { turnover, sport offers a context in } \\
\text { which the necessity of shared } \\
\text { leadership is promoted. }\end{array}$ & $\begin{array}{l}\text { Interviews } \\
\text { (31 players \& } \\
\text { coaches) }\end{array}$ & Functional & $\begin{array}{l}\text { Transfer: the model of } \\
\text { shared leadership in the } \\
\text { changing environment of } \\
\text { sport enables functional } \\
\text { value for business } \\
\text { organisations. }\end{array}$ & Firm & 5 \\
\hline $\begin{array}{c}\text { Khan et al. } 2013 \\
\text { [93] }\end{array}$ & $\begin{array}{l}\text { Employees express favourable } \\
\text { attitudes (identification, } \\
\text { organisational citizenship } \\
\text { behaviour) to an employer if they } \\
\text { are aware of its socially responsible } \\
\text { actions (sponsoring sports). }\end{array}$ & $\begin{array}{c}\text { Survey } \\
\text { (246 employees of } \\
\text { sponsoring firms) }\end{array}$ & $\begin{array}{l}\text { Emotional } \\
\text { Functional }\end{array}$ & $\begin{array}{l}\text { Platform: sponsoring } \\
\text { activities enable emotional } \\
\text { value amongst employees. }\end{array}$ & Firm & 5 \\
\hline $\begin{array}{c}\text { Kim et al. } 2003 \\
{[44]}\end{array}$ & $\begin{array}{l}\text { Sport sponsors benefit from the } \\
\text { relationship quality between sports } \\
\text { property and its customers. The study } \\
\text { shows that consumers who perceive a } \\
\text { higher level of relationship quality are } \\
\text { also more likely to form a positive } \\
\text { attitude and greater purchase } \\
\text { intentions towards sponsors and their } \\
\text { products. }\end{array}$ & $\begin{array}{l}\text { Survey (474 } \\
\text { university } \\
\text { students) }\end{array}$ & $\begin{array}{l}\text { Functional } \\
\text { Emotional } \\
\text { Economic }\end{array}$ & $\begin{array}{l}\text { Platform: sport enables } \\
\text { value creation for } \\
\text { sponsoring brands. } \\
\text { Transfer: the expected } \\
\text { value of the sponsorship is } \\
\text { dependent on the } \\
\text { relationship between } \\
\text { sports property and its } \\
\text { customers. }\end{array}$ & $\begin{array}{c}\text { Brand } \\
\text { Business }\end{array}$ & 2 \\
\hline $\begin{array}{c}\text { Kwak and Kang } \\
2009[51]\end{array}$ & $\begin{array}{l}\text { The congruence between a customer } \\
\text { and the team, as well as the perceived } \\
\text { quality, has a directly positive effect } \\
\text { on the purchase intention while the } \\
\text { perceived quality also acted as a } \\
\text { mediator between self-image } \\
\text { congruence and purchase intention. }\end{array}$ & $\begin{array}{l}\text { Survey (260 sports } \\
\text { event attendees) }\end{array}$ & $\begin{array}{l}\text { Economic } \\
\text { Functional } \\
\text { Symbolic }\end{array}$ & $\begin{array}{l}\text { Transform: from symbolic } \\
\text { value (identification with } \\
\text { the sponsoring brand) } \\
\text { and functional value } \\
\text { (affinity with the brand) } \\
\text { to economic value. }\end{array}$ & Customer & 1 \\
\hline
\end{tabular}




\section{Continued}

\begin{tabular}{|c|c|c|c|c|c|c|}
\hline $\begin{array}{l}\text { Lee et al. } 2012 \\
\qquad[55]\end{array}$ & $\begin{array}{l}\text { The study enables us to begin to } \\
\text { document the societal impact of } \\
\text { sports-based social programmes as } \\
\text { valued communication assets. }\end{array}$ & $\begin{array}{l}\text { Survey } \\
\text { (221 university } \\
\text { students) }\end{array}$ & $\begin{array}{l}\text { Social } \\
\text { Functional } \\
\text { Economic }\end{array}$ & $\begin{array}{l}\text { Platform: sport offers a } \\
\text { context for showing firm's } \\
\text { good citizenship, which, } \\
\text { in the long run, promotes } \\
\text { business. }\end{array}$ & $\begin{array}{l}\text { Society } \\
\text { Firm }\end{array}$ & 1 \\
\hline $\begin{array}{c}\text { Lorgnier and } \\
\text { Che-Jen } 2014[88]\end{array}$ & $\begin{array}{l}\text { Coopetition is an important strategy } \\
\text { in sport tourism in business to } \\
\text { business networks }\end{array}$ & $\begin{array}{l}\text { Interviews \& } \\
\text { observation } \\
\text { (11 non-profit, } \\
\text { for-profit \& } \\
\text { public } \\
\text { organisations) }\end{array}$ & $\begin{array}{l}\text { Economic } \\
\text { Functional }\end{array}$ & $\begin{array}{l}\text { Platform: economic and } \\
\text { functional values create in } \\
\text { coopetition situation. }\end{array}$ & $\begin{array}{l}\text { Firm Sports } \\
\text { product }\end{array}$ & 4 \\
\hline $\begin{array}{l}\text { Madichie } 2009 \\
{[96]}\end{array}$ & $\begin{array}{l}\text { Sport provides a context that extends } \\
\text { the understanding of general } \\
\text { management strategies in the } \\
\text { globalised environment. }\end{array}$ & $\begin{array}{l}\text { Critical analysis of } \\
\text { media reports }\end{array}$ & Functional & $\begin{array}{l}\text { Platform: sport provides } \\
\text { functional value by } \\
\text { elaborating different } \\
\text { management strategies in } \\
\text { international business. }\end{array}$ & Firm & 5 \\
\hline $\begin{array}{c}\text { Olkkonen } 2001 \\
{[91]}\end{array}$ & $\begin{array}{l}\text { A firm creates value by exploiting its } \\
\text { partner's networks. }\end{array}$ & $\begin{array}{l}\text { A qualitative case } \\
\text { study of a } \\
\text { sponsorship } \\
\text { arrangement }\end{array}$ & $\begin{array}{l}\text { Symbolic } \\
\text { Functional }\end{array}$ & $\begin{array}{l}\text { Platform: Value will be } \\
\text { created in networks. }\end{array}$ & Firm & 4 \\
\hline $\begin{array}{l}\text { Pichot et al. } 2009 \\
\quad[92]\end{array}$ & $\begin{array}{l}\text { The study explores how the practice } \\
\text { of sports is taken seriously when } \\
\text { organisations are reconstructing their } \\
\text { human resource policies. }\end{array}$ & $\begin{array}{l}\text { Interviews } \\
\text { (14 company } \\
\text { decision makers })\end{array}$ & $\begin{array}{l}\text { Emotional } \\
\text { Functional }\end{array}$ & $\begin{array}{l}\text { Platform: collective } \\
\text { activities around sport } \\
\text { enable emotional and } \\
\text { functional value. }\end{array}$ & Firm & 5 \\
\hline $\begin{array}{l}\text { Pritchard et al. } \\
\quad 2010 \text { [98] }\end{array}$ & $\begin{array}{l}\text { Fan identification with a sport } \\
\text { established through two similar yet } \\
\text { distinct psychological processes: } \\
\text { affinity and affiliation. Identification } \\
\text { can be created when the team's image } \\
\text { is congruent with the fans' own } \\
\text { personality. }\end{array}$ & $\begin{array}{c}\text { Survey } \\
\text { (430 university } \\
\text { students) }\end{array}$ & $\begin{array}{l}\text { Emotional } \\
\text { Symbolic }\end{array}$ & $\begin{array}{l}\text { Platform: team and } \\
\text { community serve as } \\
\text { platforms for value } \\
\text { creation for the fan. } \\
\text { Affinity and and } \\
\text { affiliation facilitate the } \\
\text { process. }\end{array}$ & $\begin{array}{c}\text { Customer } \\
\text { Sports product }\end{array}$ & 4,6 \\
\hline $\begin{array}{c}\text { Reiser et al. } 2012 \\
{[5]}\end{array}$ & $\begin{array}{l}\text { Sport sponsorship positively impacts } \\
\text { stock returns. }\end{array}$ & $\begin{array}{l}\text { The event-study } \\
\text { methodology } \\
\text { (629 sponsorship } \\
\text { deals) }\end{array}$ & Economic & $\begin{array}{l}\text { Economic value is spurred } \\
\text { by the investors' beliefs on } \\
\text { the benefits of } \\
\text { sponsorship. }\end{array}$ & $\begin{array}{c}\text { Brand } \\
\text { Firm }\end{array}$ & 1,2 \\
\hline $\begin{array}{l}\text { Richelieu and } \\
\text { Korai } 2012[53]\end{array}$ & $\begin{array}{l}\text { Underlies the importance of culture, } \\
\text { identity and symbolism while } \\
\text { building a sports team brand. }\end{array}$ & $\begin{array}{c}\text { Group \& } \\
\text { individual } \\
\text { interviews } \\
\text { (120 university } \\
\text { students) }\end{array}$ & Symbolic & $\begin{array}{l}\text { Fans use the symbolic, } \\
\text { iconic and indexical } \\
\text { dimensions of a brand to } \\
\text { define their own identity. }\end{array}$ & $\begin{array}{l}\text { Consumer } \\
\text { Brand Sports } \\
\text { product }\end{array}$ & 1 \\
\hline $\begin{array}{l}\text { Sheth and Babiak } \\
\quad 2010[131]\end{array}$ & $\begin{array}{c}\text { Professional managers } \\
\text { should embrace a strategic } \\
\text { approach to CSR to develop } \\
\text { sports businesses. }\end{array}$ & $\begin{array}{c}\text { Survey } \\
(237 \text { sport } \\
\text { managers })\end{array}$ & $\begin{array}{l}\text { Emotional } \\
\text { Symbolic } \\
\text { Functional }\end{array}$ & $\begin{array}{l}\text { Transform: from } \\
\text { emotional and symbolic } \\
\text { to functional value. }\end{array}$ & $\begin{array}{c}\text { Society } \\
\text { Sports product }\end{array}$ & 3 \\
\hline Smith 2010 [90] & $\begin{array}{l}\text { To be successful, sports-city } \\
\text { zones need to be planned as such } \\
\text { and not merely employed as } \\
\text { convenient brands for existing } \\
\text { event facilities. }\end{array}$ & $\begin{array}{l}\text { A comparative } \\
\text { analysis (four } \\
\text { sport schemes) }\end{array}$ & $\begin{array}{c}\text { Social } \\
\text { Functional }\end{array}$ & $\begin{array}{l}\text { Platform: sport creates } \\
\text { value for marketing city } \\
\text { zones. }\end{array}$ & Society & 1,4 \\
\hline
\end{tabular}




\section{Continued}

\begin{tabular}{|c|c|c|c|c|c|c|}
\hline Thomas 2014 [65] & $\begin{array}{l}\text { The results of the study show that if } \\
\text { there is a lack of fit between the } \\
\text { sponsor and the sponsored event, } \\
\text { consumers }\end{array}$ & $\begin{array}{l}\text { Focus group } \\
\text { (198 sport fans) }\end{array}$ & $\begin{array}{l}\text { Functional } \\
\text { Symbolic }\end{array}$ & $\begin{array}{l}\text { Transform: the functional } \\
\text { value does not form if the } \\
\text { symbolic value is not } \\
\text { there. }\end{array}$ & $\begin{array}{l}\text { Brand } \\
\text { Customer } \\
\text { Firm }\end{array}$ & 2,6 \\
\hline $\begin{array}{l}\text { Tsiotsou } 2012 \\
{[101]}\end{array}$ & $\begin{array}{l}\text { Aaker's brand personality to fit sport: } \\
\text { scale does not fit sport team } \\
\text { personality, scale consists of five } \\
\text { dimensions: competitiveness, } \\
\text { prestige, morality, authenticity, and } \\
\text { credibility, which can be used for } \\
\text { branding purposes. }\end{array}$ & $\begin{array}{l}\text { Survey } \\
\text { (301 random } \\
\text { consumers) }\end{array}$ & $\begin{array}{l}\text { Emotional } \\
\text { Functional } \\
\text { Symbolic }\end{array}$ & $\begin{array}{l}\text { Transform: a fan's } \\
\text { emotional attachment to } \\
\text { the team's brand leads to } \\
\text { increased team loyalty }\end{array}$ & $\begin{array}{l}\text { Sports product } \\
\text { Firm } \\
\text { Society }\end{array}$ & 2,6 \\
\hline $\begin{array}{c}\text { Tsiotsou } 2013 \\
{[102]}\end{array}$ & $\begin{array}{l}\text { A hierarchy of effects, approach, } \\
\text { cognition-affect-conation, can } \\
\text { explain how strong consumer-team } \\
\text { relationships can be developed. } \\
\text { Sports team managers should use } \\
\text { the brand relationship and team } \\
\text { measures and develop initiatives } \\
\text { that ensure that consumers find } \\
\text { self-expressive value in the team. }\end{array}$ & $\begin{array}{l}\text { Survey }(287 \\
\text { random } \\
\text { consumers) }\end{array}$ & $\begin{array}{l}\text { Functional } \\
\text { Symbolic }\end{array}$ & $\begin{array}{l}\text { Transform: positive } \\
\text { affection and cognition } \\
\text { towards team's brand } \\
\text { leads to increased } \\
\text { customer loyalty. }\end{array}$ & $\begin{array}{c}\text { Firm } \\
\text { Customer }\end{array}$ & 2,6 \\
\hline $\begin{array}{l}\text { Uhrich et al. } 2014 \\
\qquad[16]\end{array}$ & $\begin{array}{l}\text { The study suggests that adding CSR } \\
\text { to sponsorship leverages sponsorship } \\
\text { for moderately low congruity brands } \\
\text { to the sponsored events. }\end{array}$ & $\begin{array}{l}\text { Survey } \\
\text { (437 university } \\
\text { students) }\end{array}$ & $\begin{array}{l}\text { Emotional } \\
\text { Functional } \\
\text { Economic }\end{array}$ & $\begin{array}{l}\text { Transform: from } \\
\text { emotional and symbolic } \\
\text { value to economic value. }\end{array}$ & Sponsorship & 1,3 \\
\hline $\begin{array}{l}\text { Woratschek et al. } \\
\quad 2014 \text { [17] }\end{array}$ & $\begin{array}{l}\text { Presents a sport-value framework } \\
\text { which provides } 10 \text { foundational } \\
\text { premises on value co-creation in } \\
\text { sports management. }\end{array}$ & $\begin{array}{l}\text { Critical review of } \\
\text { literature }\end{array}$ & Functional & $\begin{array}{l}\text { Platform: presents sport } \\
\text { value framework. }\end{array}$ & & 4 \\
\hline $\begin{array}{l}\text { Walters and } \\
\text { Tacon } 2010[15]\end{array}$ & $\begin{array}{c}\text { The study demonstrates how CSR can } \\
\text { be implemented within sports } \\
\text { organisations. }\end{array}$ & $\begin{array}{l}\text { Interviews ( } 26 \\
\text { representatives } \\
\quad \text { of sports } \\
\text { organisations) }\end{array}$ & Functional & $\begin{array}{l}\text { Platform: sport offers a } \\
\text { context for conducting } \\
\text { CSR activities }\end{array}$ & $\begin{array}{l}\text { Sports product } \\
\text { Society }\end{array}$ & 1,3 \\
\hline
\end{tabular}

transformed from one type to another. Although value transformation can take several forms, two of these emerged as the most obvious. Firstly, through sponsorship, a fan's feelings about a team or athlete (i.e. emotional value) could be extended to the sponsor's brand and thus influence consumer attitudes towards the brand (i.e. functional value) and increase sales (i.e. economic value). Secondly, as value creation does not happen in a vacuum, companies must take into consideration the value climate of the surrounding community. Companies' actions should be adapted not only to fit the characteristics of fan communities (i.e. symbolic value), but also to fit the values of the geographical communities they operate in (i.e. social value).

Due to these many shades of value and their interconnectivity, it seems reasonable to argue that value creation through sport is a complex process. Based on the reviewed literature it is suggested that the creation of value in sport and business co-operation arises from complex configurations of resources. Adopt- 
ing the value co-creation concept [35], we propose that value cannot be embedded in a firm's output and captured by price. Quite the contrary, it is expected that value can only be created when firms integrate sport into their market offerings in ways that inspire customers symbolically and emotionally. Value is created only when offerings are "used" by customers in meaningful ways. As a guiding example, consider a firm who sponsors a Premier League football team. A brand's logo on the kit might be expensive but it serves the value of sponsorship poorly. This is because the value arises-if at all-when customers and stakeholders engage with the sponsored team in a way that creates positive buying intentions, inspires positive word-of-mouth, or deepens customer loyalty.

\subsection{Brands and Sponsorship as Value Creators}

Literature on branding and sponsorship has become one of the major topics in the context of sport. This topic has been approached from several viewpoints, such as sports branding, branding through sport, and customer-based brand equity. Brands, in general, have been characterised as powerful tools for positioning and differentiating the company from its competitors. Especially strong brands and brand equity have been shown to create value for the firm, its partners, and customers [56].

Also, within the branding literature in sport, the most powerful concept in value creation seems to be brand equity and its different antecedents. A closer look at the topic reveals that the outcomes of brand equity are multifaceted and related in sports and also through sports perspectives. Brand equity has been essential especially in the team sports industry. Bauer et al. [57] examined the antecedent of customer-based brand equity in team sports as well as its positive consequences on the number of spectators. Further research on the topic has addressed the importance of team-sports brand equity. The customer-based brand equity of a sports team has been shown to affect different consumers' behavioural intentions [58] as well as brand extension opportunities [54]. According to the study of Yoshida and Gordon [59], the quality of the relationship (between a customer and a sports team) affects brand equity, which in turn affects customers' behavioural intentions (e.g. attendance and spending).

However, strong team brand equity not only provides value for the team and its commercialisation but also attracts partners. Strong team brands also serve as interesting targets for sponsors due to the high levels of media and consumer attention. Since the 20th century, sponsoring and its effectiveness has been one of the major issues in studies on sports marketing. Much of the interest in research towards sponsoring has been focused on brand awareness, brand image, brand positioning, and consumer attitudes [60]. The literature has clearly shown the positive effects of sponsorship on company brands and brand equity [49]. Moreover, strong brands themselves have advantages in sport sponsorship. As Herrmann et al. [61] have shown, spectators recall and consider strong brands more over the lesser known brands. However, integrating sponsorship into other 
parts of the promotional mix has received less focus in academic research. In the research of Carrilat and d'Astous [62] it was shown that a sponsorship advertising interface does not necessarily provide added value in terms of positive consumer attitudes if the brand becomes too prominent in the event. Even so, a moderate sponsorship presence during a sports event leads to positive attitudinal outcomes for an advertised branded product than advertising alone [62].

Also, the close relationship between the sponsor and sponsored party has been found to provide a solid basis for reciprocal value creation in sponsorship relationships. In particular, the research concerning the fit between sponsor and sponsored party has gathered much attention [62] [63] [64] [65]. Gwinner and Bennett [60] found that the event-sponsor fit has a positive effect on consumer attitudes towards the sponsor, which eventually leads to purchase intentions. In order to succeed in sponsoring, firms should evaluate and plan their sponsoring contracts carefully and keep in mind the concept of fit. In addition, athlete endorsers have been found to be effective tools in sponsoring both sporting events [66] and non-sports products [63].

Besides fit, the studies have also paid attention to the importance of relationship quality in sponsorship relationships. According to Farrelly [66], the changing perceptions of value, opportunity, and responsibility dilute and terminate sponsorship relationships. On the basis of these findings, Farrelly [66] emphasises the importance of a high level of commitment as well as an explicit description of roles and responsibilities in a reciprocal value creation in sponsorship relationships. Finally, it has been shown that investors also acknowledge the value of sponsorship deals. Reiser et al. [5] found that sports sponsorship announcements may positively impact a firm's stock return, demonstrating the role of sports sponsorship as a value creating investment with favourable effects on expected sales and profit.

\subsection{The Value of CSR in and through Sport}

Corporate social responsibility (CSR) has become an important area for a wide range of organisations and for the managers that work within them. This is particularly true in the sports industry. Literature on sports related CSR has grown quickly over the last few years [15] [68] [69]. CSR has evolved from a charitable or philanthropic activity to a core element in management strategy with the understanding that CSR activities can add value to a business [70]. Protecting corporate reputation, competitor differentiation, brand loyalty development, competitive advantage, and improved financial performance are some of the benefits that an organisation can realise through a strategic CSR approach [71] [72].

CSR is closely related to sport. The nature of sport lends itself to being uniquely positioned to influence society in general and communities in particular [9]. According to Smith and Westerbeek [9], sport can be used as a vehicle for deploying CSR. Mass media distribution and communication power, youth appeal, positive health impacts, social interaction, improved cultural understand- 
ing, and immediate gratification are the beneficial features of sport that make it an appealing CSR partner for companies [9].

The relationship between sport and CSR can be seen from two perspectives: 1) in sport and 2) through sport. "In sport" is used by the sports organisations trying to connect with their stakeholders (fans, players, media, community, partners, etc.) and enhance their common values. The in-sport concept creates a platform for the through-sport concept, which is normally used by commercial firms/partners (not sport) setting CSR activities (content of sponsorship) through sports organisations that are trying to link or communicate with stakeholders, who can be seen as customers from a company perspective, to strengthen the brand or for commercial purposes. "In sport" can occur alone (e.g. a sports organisation setting CSR activities for stakeholders trying to enlarge the fan base), but the "through sport" concept cannot be implemented without a sports organisation. In addition to brand building, firms face a growing demand from their operational environment to demonstrate their commitment to creating shared value. Shared value refers to activities that generate not only economic value for firms but also produce value for society by addressing its challenges [70]. Smith and Westerbeek [9] and Filizöz and Fisne [73], for example, have found out that sports provide companies with an effective way of creating social value and expressing their commitment to surrounding communities.

The brand is the most valuable asset for professional sports organisations. In no other sector does the theme of identity, image, and reputation play as central a role as in the sports arena [74]. The value of CSR connected to a professional sports organisation lies in strong brand equity, which makes higher ticket prices acceptable and allows for the sale of club merchandise. Trying to achieve as good a sporting performance as possible is not enough for stakeholders (fans, partners, media, etc.). Professional sports organisations will implement their CSR activities amongst stakeholders, because it is an organisation's duty to maximise its long-term positive impact on society, while simultaneously minimising its negative effect [68].

The rapid commercialisation of sport has brought challenges for the management of professional sports organisations. The side-effects of this commercialisation have been mounting criticism for various business practices, such as poor governance, financial problems, corruption, and controversial behaviour of some players [68]. Various theories have been introduced to explain how these managerial challenges can be solved through CSR in professional sports organisations, including the stakeholder theory [15], the stewardship theory [75], and the resource-dependence theory [76]. Smith and Westerbeek [9] have summarised the CSR relationship between firms and sport: the implementation of CSR is a crucial action for management in attempting to optimise the effects of brand development. Without the financial backing of corporate partners, the value of sport as a vehicle for social responsibility is limited and the scope for improving this flow of resources to sport is substantial. 


\subsection{Sport as a Network and Platform}

Li et al. [77] have introduced "a sport activity model", which considers sporting events as core products produced by sports organisations and firms. Production is often referred to as the production of a sport in competition [78]. However, it is difficult to define, for example, what a "product" of a sports league is. Based on the work of Vargo et al. [35], Woratschek et al. [17] have argued that value creation in sport cannot be fully understood on the basis of goods-dominant logic, in which value is seen as being created in exchange and measured by this exchange transaction. Goods-dominant logic (G-D logic) separates the role of "producer" from "consumer". Seen from a G-D logic perspective, the value is "embedded in firm output and captured by price" [17]. Service-dominant (S-D) logic refers to the process in which value is co-created in interactions amongst producers and consumers through the integration of resources and the application of competencies [35]. From the viewpoint of S-D logic, sports customers are not just consumers, but value co-producers when they participate in sporting events as spectators. From this perspective, value cannot be created solely by sports organisations and firms. Value is created jointly with various customer groups such as fans, VIP guests, other spectator groups, and other stakeholders [17]. Service providers can only offer value propositions as input for potential value creation. Value co-creation requires the customer to integrate the provider's value proposition with his or her own skills, as well as with public, market-facing, and other resources [17]. In the case of sports events, sports organisations and firms can provide a platform that enables all types of stakeholders, including fans and other spectators, to co-create value [79].

Athletes, clubs, associations, sports events, etc. are of great interest to billions of people. That interest is full of powerful emotions, which drive many people to become fans of an athlete or a club. This kind of behaviour is one of the unique features of sport, which Steward and Smith [24] describe as a heterogeneous and ephemeral experience mired in the irrational passions of fans, commanding high levels of product and brand loyalty, optimism and vicarious identification. This kind of emotionally loaded environment is important, in terms of value creation, for those actors working in sport (e.g. athletes, clubs, associations). On the other hand, this kind of environment becomes a platform for many kinds of acts and actors who want to gain a competitive advantage through the sports environment (e.g. commercial partners, media, public actors).

Competition is considered by many as the "heart and soul of sport management" [80]. The possibility of winning or losing is a great driving force for competitors, encouraging them to train and compete. The uncertainty of the outcome of the competition is an important factor regarding the value creation process. It will increase the interest of many people following the competition and the competitors. In order to maintain beneficial uncertainty, it is important to pay attention to co-operation concepts, including strategic alliances, network and cluster strategies [80]-[86]. 
Competition and co-operation can occur at the same time in business networks. The coopetition concept has been developed to describe the simultaneous competition and co-operation amongst two or more actors [87] [88]. According to Benijts et al. [89], a sports league is an example of a value network where clubs compete against each other but also co-operate during the season for marketing purposes, for example. The theory of business networks in marketing argues that a sports league is a marketing channel network. This unique feature of sports leagues influences the value creation system of the marketing network channel. Without an appropriate balance between competition and co-operation, the business-sport nexus cannot realise its value creation potential. In order to avoid underperforming, it is suggested that sports teams should be made equal to each other as the competitive balance increases companies' interest in sponsoring the sport [89]. The value network approach and the concept of coopetition also help team managers to understand how "sports leagues influence the teams' corporate business-to-business market which, in turn, will influence the teams' financial position" [89].

The sports context enables many other value-creation platforms. In the reviewed literature, the relationship between sport and the city has been introduced as the sports zone and the sports city concepts. The sports zone/city is a rather abstract concept. Its application usually takes one of two forms: designating one zone of a city as a sports city; or branding the whole city as a sports city [90]. The value of sports cities lies not in the visitors and tourists attending the sports events' but in them being influenced to attend because of the city's reputation. Sports city zones have also been development anchors for urban redevelopment [90].

Firms are taking the opportunity to create competitive advantages through sports sponsorship. The network approach is one of the strategies in sponsorship. Different network actors bring not only their own resources and capabilities, but also their own network of value adding relationships to the arrangement [91]. The firm's value as a network partner is based on its "network identity", a combination of its core competencies, other network connections and, finally, its ability to create efficiency in the network itself [91].

\subsection{Sport as a Tool for Developing Organisations Internally}

In recent years, there has been an increasing amount of literature that bases its theoretical and empirical background on the phenomenon of sport within management and organisation studies. In striving for ever greater economic value, organisations are looking for fresh ideas from radically different industries, such as sport. However, as Wolfe et al. [10] have argued, sport as a research context still has unrealised potential. As one of its aims, our systematic literature review demonstrates how the research potential of sport for developing organisations internally is fulfilled from the angle of value creation.

The reviewed studies demonstrate that the value of sport for developing organisations internally is manifested from two perspectives: 1) sport as a vehicle, 
and 2) sport as a model. The sport as a vehicle perspective highlights the positive epithets (e.g. enthusiasm, respect, commitment to colleagues, community spirit) of sport by examining how the practice of sport is taken seriously when organisations are reconstructing their human resource policies [92] and strengthening organisational commitment amongst employees [93]. Amongst the literature reflecting this perspective, the most immediate value transformation process occurs from emotional to functional to economic value.

Pichot et al. [92] examined what kind of function sport may have in firms within the framework of human resource management policy. As a result of the analysis, the authors propose sport, as a constituent of organisational identity, can change itself into effective communication tool. Collective activities around sport blur the distinction across hierarchical levels, foster official as well as unofficial cooperation amongst employees, and thus underline the value of equality and effective team working. In addition, the study illustrates the use of sport as a motivation and training tool and, not to mention, how the sporting activities are used to reduce the risk of burnout in the firms under study.

Supporting the main conclusions of the study by Pichot et al. [92], Khan et al. [93] argue that, as an implication of their research, sport-linked activities might work as a vehicle for internal marketing purposes. Their study demonstrates that a firm that sponsors sport reflects the image of being a socially responsible organisation amongst its employees. According to the research, it is likely that employees express positive attitudes, such as identification and organisational citizenship behaviour, towards the employer if they are aware of the sponsoring. As Khan et al. [93] conclude, the internal impacts of sports sponsoring are still, nevertheless, overshadowed by its external influences.

However, a considerable amount of literature has been published on following the logic of sport as a model. The sport as a model perspective utilises the context of sport as a microcosm of larger society, however, as life simplified [94]. Following the logic of this perspective, the studies we have reviewed have underlined the concept of change. The concept of change is elaborated in the studies exploring the phenomenon of leadership [11] [95] and strategic management [96]. Amongst the studies covering this perspective, the most obvious value transformation occurs from functional to economic value.

Burnes and O'Donnell [11] composed a qualitative study to examine the leadership qualities that might be transferable from sport to business. Based on their analysis, the authors propose that change as a contextual factor could be a source of leadership wisdom from sport. Due to the continuous change sports leaders face in their work, it is believed that they are especially adaptable to change. Adopting the leadership theme above, Kerwin and Bopp [95] explored the demand for shared leadership in the dynamic sports environment. As a main finding, the authors promote the role and necessity of shared leadership in a contextual environment where the team roster is changing constantly due to player turnover. 
Madichie [96] demonstrates how the globalisation of the football industry has affected management practices in sports organisations. Using the sport as a model perspective, the study extends the understanding of general management strategies in the context of international business. These days, sport is not a mere entertainment business but rather a serious global industry that could provide a model for business firms. Respectively, research that uses sport as a means for developing organisations internally would have potential value within academic management research.

\subsection{Congruence and Identification in Value Creation}

The final theme in our review captures the aspects of congruence and identification. The previous sports management and marketing literature has found congruence and identification essential and indispensable attributes in the value creation process and they are essential not only regarding individual fans [97] [98], but also for all parties in the equation, including the sports organisation/club [51], fan communities [99], sports event sponsors [100], and sponsors in general [101] [102]. Analysing the research of congruence and identification, two main theories can be uncovered which have been applied as a theoretical framework: the social identity theory [97] [99] and the congruity theory [51] [100].

The social identity theory is a social psychological theory that explains group membership, group processes, and intergroup relations [103] [104]. The basic premise of the social identity theory is that "one's social identity derives from the social categories to which he or she belongs, such as a demographic grouping, employment affiliation, or team membership" [97]. The value of social identification for a sports entity lies in the process of "favouring the home team". As the identification becomes stronger, the more likely it is that an individual will be motivated to ensure the wellbeing of the group, relative to other groups.

Research has shown that identifying with a club or sports entity has numerous positive effects such as an increase in attendance [105] and spending [106], positive word of mouth [99], reduced levels of price sensitivity [107], increasing longevity in the fan's relationship with and lifetime value to the organisation [108], a decrease in switching behaviour and increased loyalty [102] [109], and fostering resistance to negative press [110]. It can be argued that identified fans are the most profitable customers a sports entity can have and, indeed, should pursue.

The congruity theory is based on the premise that people have a need for harmony in their thoughts, feelings, and behaviours and that they are motivated to maintain uniformity amongst these elements. In other words, consumers strive for cognitive consistency [100]. When the feeling of congruence between the self-image and the object under examination (e.g. a sports franchise) is reached, research shows that it can have various positive associations concerning function, such as triggering consumers to purchase goods and services [111], in- 
creased likeliness to have positive thoughts towards the organisation [100], product/brand preferences [112] [113] [114], brand/service attitude [115], consumer satisfaction and loyalty [116] [117], and consumers' product evaluation and purchase behaviours [118]. On the other hand, incongruity can have a negative effect on the way customers perceive the sponsor and their brand [65] [100].

Notwithstanding all of the research knowledge presented in numerous articles, it seems that at the grass-roots level of actual sponsorship, sports management, and marketing, there appears to be a profound lack of understanding about the possibilities of congruence and identification. In light of some of the research [65] [100], it can be argued that neither sponsors nor sports organisations have understood the importance of fostering identification and facilitating congruence on all levels. Because fans are the main targets of sponsors, there should be a combined effort to understand and serve fans better. In order to accomplish this objective, sporting entities need to recognise the possibilities of identification and congruence and sponsors need to put more effort in to brand due-diligence to verify the fit between the sponsor's brand and the entity being sponsored, in order to acquire the most value for the sponsorship investment.

\section{Discussion and Conclusion}

Using a systematic review of literature, this study has explored and analysed value creation in the nexus of sport and business. The literature we have reviewed shows that value creation has been in academia's interest. However, what has been lacking is a holistic view that brings together the various aspects of value creation in this particular area. The review provides new knowledge on various forms of value creation and particularly helps academia and practitioners to continue exploring the mystery of value co-creation through the nexus of sport and business. Before addressing the theoretical and managerial implications and mapping the avenues for further research, the main findings of the review will be presented and discussed in Figure 1.

One of the main findings of this review is the distinction between the instrumental and the metaphorical use of sport in value creation. Brand promotion and corporate social responsibility through sponsorship were identified as the most typical instrumental uses of sport. The reviewed literature showed, on the one hand, that strong sports brands (athletes, teams, and clubs) enable firms to speak to their stakeholders effectively. In terms of sport sponsorship programmes, firms may pursue higher visibility and enhanced brand equity, which are, in turn, related to economic value and incremental cash flows. On the other hand, the literature also showed that sport offers a useful channel for communicating social responsibility. The reviewed literature confirmed the presumption, based on common sense, that using sport for brand promotion is more common within professional than amateur sport, whereas amateur sport (e.g. local and youth sport) offers a suitable context for communicating a company's social responsibilities. The metaphorical use of sport was manifested in two forms. Firstly, sport was seen as a vehicle for highlighting enthusiasm, respect, 


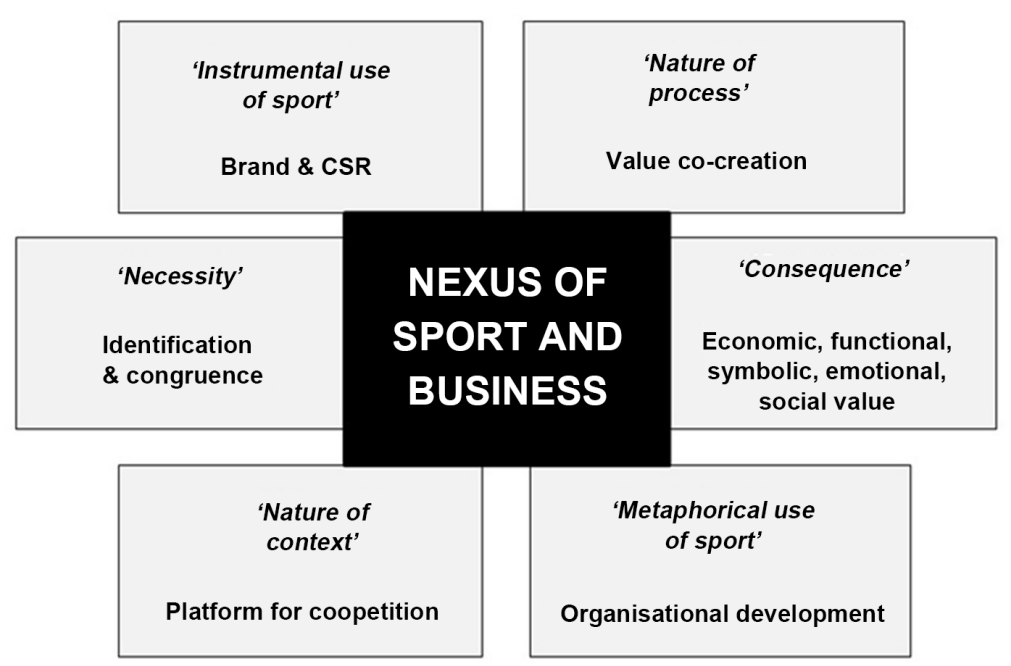

Figure 1. Value creation in the nexus of sport and business.

commitment to colleagues, community spirit, and other positive attributes of sport. Secondly, sport was described as a model, which was seen to be offering ideas and good practices for leadership and strategic management.

Sport, as the context itself, was portrayed as a value creation platform, in which there are constantly two opposite processes going on. For example, sports organisations (teams and clubs) compete with each other on the field but they co-operate with each other in order to increase the attractiveness of the league. In other words, sport is a platform for coopetition. Sport as a platform for coopetition is an interesting concept as it prompts us to look at value creation in and through sport. The reviewed literature showed that both approaches are needed in value creation. Too little competition on the field and the entire league's value proposition, in the eyes of potential sponsors, fades away. Also, too little cooperation in the league's marketing and development yields similar consequences. Without a dynamic balance between co-operation and competition, sport cannot fully exploit the value potential it has (in sport), neither can it offer tempting value propositions for companies (through sport).

The reviewed literature suggests that individual actors within the sport-business nexus (fans, athletes, company employees, and sports organisations) should have a sense that they "have joined the club". The literature clearly shows that sports organisations should provide their fans with opportunities to build a strong identification with individual athletes/players and/or teams/clubs. Identification with sporting products strengthens emotional links and offers sponsors tempting opportunities to use these attachments to promote brands. In addition to identification, the literature emphasises the need of congruence-or fit-between a fan's identity and the sponsor. It should be noted that, although the reviewed literature mainly approached identification and congruence from the fans' perspective, both identification and congruence are also useful when exploring sport's possibilities to develop firms internally. The more there is congruence between an employee's identity and an individual athlete/player or team/club, 
the more probable it is that enthusiasm, respect, commitment to colleagues, community spirit, and other positive attributes related to sport can be used to improve leadership and foster organisational change. Identification and congruence are seen as a necessity for value creation in the nexus between business and sport. Without strong identification and congruence between individuals' identities and sports products, sport cannot achieve its full potential as a value-creation platform, nor can it act as an instrument or a metaphor for value creation.

Based on the simultaneous existence of co-operation and competition-i.e. coopetition-it is no surprise that the literature describes the nature of the value creation process through the lenses of co-creation. Value is not created by individual actors, but through a complex interaction between sport and business. The literature points out that sport's value cannot be embedded in goods and then delivered to the market. Instead, value providers can only propose value through sport, but it depends on the beneficiaries as to whether or not they continue value creation through use. The reviewed literature concurs with the idea proposed by Vargo and Lusch [21] that value co-creation is a multi-actor phenomenon in which actors are not predesigned as value producers or beneficiaries. The roles can be interchangeable, but what matters is resource-integrating actors who can co-create value through holistic and meaning-laden experiences. It is worth noting that all actors within the nexus can take a lead in developing these value-creating experiences.

In accordance with co-creation, the reviewed literature showed that value that is created within and through sport can take various forms. Economic, functional, emotional, symbolic and social values were identified. Based on the reviewed literature (see Table 1), the instrumental use of sport highlighted the co-creation processes of emotional and symbolic value. Through brand promotion activities in close collaboration with professional sport, firms may benefit from the emotions attached to sport. Similarly, through CSR activities on a platform, which amateur sport in particular provides, firms may above all gain symbolic value alongside emotional value. The metaphorical use of sport exposed the co-creation processes of functional and emotional value. Through the logic of the vehicle metaphor, businesses are allowed to utilise the emotion-laden sport environment. A close relationship with sport helps to spread the positive epithets surrounding sport across certain fields. Similarly, through the model metaphor, applicable organising and leading practices in a sports environment manifest functional value, when those are transferred from one field to another. We argue that these particular values are co-created in this sport-business nexus due to the business partnership with sport. We assume that if the nexus were formed with some partner other than sport, the co-creation process would have emphasised other forms of value. This particular nexus allows for businesses to get the hands-on value creation processes that the features of sport enable.

The findings resonate with earlier studies [40] [119] that have emphasised that value is not an objective property but a perceived utility acquired by the benefi- 
ciary. All value types have their own characteristics; however, they are not as separate as they might seem. On the contrary, the literature shows that they are highly interdependent and capable of transforming from one form to another. In the reviewed literature (see Table 1), the interaction of values occurred through three mechanisms. Platform, transfer, and transform were identified. In the cases of platform and transfer, sport offered an arena for value co-creation. Instead, the transform mechanism underlined the interdependency of various values. In our results, we presented different angles on value co-creation. Under the topic "Brands and sponsorship as value-creators", the interaction of values occurred mostly through the "transform" mechanism. For example, a fan's emotional attachment to an athlete can be transformed into an economically important asset to the firm. Similarly, the reviewed literature regarding the "Value of CSR in and through sport" showed the interaction of values to emerge particularly in the transformation process. In many articles, the emotional or symbolic value provided in a sports environment was transformed into functional and economic value for firms. However, what still seems to be lacking in sport is a platform for CSR activities and thus an arena, as such, for symbolic value for business partners. In other words, earlier research has identified that symbolic and emotional value are transformable to other forms of value but research that promotes sport as a CSR co-creation platform of symbolic value for both partners in the nexus is still vague.

\subsection{Theoretical Implications}

This study proposes several contributions to management literature as follows.

Firstly, we extend the prevailing knowledge in management literature about value co-creation in the nexus of different fields. Particularly in critical management studies, which encourage scholars to bring forward new perspectives. Metaphors for management practices are sought, for example, from the military [120], art [121], healthcare [122], religious institutions [123], and sport [94]. It is argued that each field provides certain added value for other fields as well as general management knowledge. However, many studies under these topics are primarily benchmarking how knowledge in these particular fields could be transferred to another field. Instead, our study exposes how value is added through a co-constructive process amongst the partners in the nexus, i.e. sponsoring companies and sports organisations, and sport consumers. The studies that we have reviewed make their respective explicit contributions to management studies. In this study, we redirected these particular studies and their intended core messages by recognising how these respective studies participate in discussions about value co-creation in the nexus of sport and business. In other words, we uncovered previously hidden aspects in the studies we reviewed. Through our analysis, we proposed that the nexus of different fields, e.g. sport and business, allowed the partners in the nexus to have access to value creation processes that would have been challenging without the nexus. For example, the 
co-creation process of emotional value is elusive for firms without a nexus partnership with sports organisations. Yet, although the nature of sport is very emotional, in the sport-business nexus, sport cannot work as an emotional value provider without the firm, which acts as an emotional value beneficiary.

Secondly, the review illustrates that the service-dominant logic of value co-creation [26] is an appropriate framework for understanding value co-creation within the nexus of sport and business. The reviewed studies show that value is co-created in collaboration between various actors. In so doing, the findings speak in favour of the service ecosystem view on value co-creation [21]. We deem the service ecosystem approach as promising, particularly in the nexus of sport and business, as it allows for the coexistence of competition and collaboration (i.e. coopetition), and emphasises the role of institutional arrangements in systems of value co-creation.

Thirdly, the review illustrates the interdependent nature of economic, functional, emotional and symbolic values, and therefore contributes to value co-creation literature. Values are not as independent as suggested in earlier studies. Sheth et al. [40], for example, have argued that consumption values are "independent, relating additively and contributing incrementally to choice". By emphasising the interdependence of values in contrast to the additivity of values, the findings of the literature review concur with the new economic sociology [124] [125], which argues that nothing is valuable until it is made valuable. Value is neither an objective feature of the entity, nor a subjective opinion of the evaluator, but a phenomenon that emerges from the nexus of sport and business.

Moreover, our study advances the prevailing sport management research. One of the pioneers in the field of sport management research, Simon Chadwick, has pointed out the need for research that amalgamates mainstream management literature with sport management research. According to him, what is needed is an approach "that involves a more consensual relationship between the generic and the sport management literatures." [126]. Our study has answered to calls for a multidisciplinary approach in sport management research [22] [28] [29] as follows: unlike much of the previous sport management research, which has taken a purely functional perspective in order to understand the causal connections in the value creation process between sport and fans, our research contributes to the theoretical understanding of the value creation process in the nexus of sport and business. Worth noting is that in the current research, values are seen as consequences of actions, not as prerequisites for actions. However, we do not disagree with the notion that in all social settings values play an important role in defining what is desirable and acceptable and what is not [127]. On the contrary, the findings of the literature review speak for a broader understanding of congruence. Our findings suggest that congruence should not be limited to the fit between the brands and sports products [51] [100] [128], but should include the parallel between values (as prerequisites for trying something) and actions (as consequences of doing something). 


\subsection{Managerial Implications}

We claim that value creation is realised in the nexus of sport and business, not between sport and business. It is imperative for managers in business and sport understand this. Value co-creation refers to the process in which value is co-created in interactions amongst various actors through the integration of resources and the application of competencies [21]. As an illustrative example and from the viewpoint of S-D logic, sports customers are not just consumers, but value co-producers when they participate in sporting events as spectators.

As a managerial implication for business managers, this study underlines the necessity of recognising and taking into consideration the particular features of sport and how these features fit with their organisational environment and objectives respectively. This is in line with Liden and Antonakis [129] and Porter and McLaughlin [130], who have argued that contextual knowledge in management and organisation studies should be considered more seriously.

Particularly for those sports managers who work in leagues, league clubs, or in comparable organisations, where inclusion is restricted (even if the rules do include relegation and promotion), it can be useful to realise that successful business practices demand simultaneous competition and co-operation. This kind of practice is called coopetition. Competitors are not trying to push other competitors out of the market. They are co-operating, especially in commercial actions.

Sports managers should understand that brand building of sports organisations could be a profitable action too. The development of a brand can help sports organisations to connect better with their customers (fans and spectators) as well as increase the organisation's desirability in the eyes of sponsors. A large fan base is an interesting prospect from a company point of view. From a sponsorship perspective, there needs to be a demand for sports entities to know their fans and potential fans, which calls for systematic information gathering, upon which fruitful collaboration and greater value creation can be built.

Also, in a broader sense, sports managers should be aware of the in and through sports perspectives that are essentially intertwined with each other. Especially from a value-creation point of view, it is often sports managers who play a major role in the interaction between sport and business. However, both sports managers and business managers should pay attention to the different sources of values as well as the co-creative and interactive nature of value creation in the context of sports. Accordingly, the economic value (sources of sales and profit) and functional value (sources of organisational effectiveness) are often dependent on the emotional, symbolic, and social values that different actors form in the interface between sport and business. Thus, in accordance with S-D logic, the different actors participating in sports are both value creators and value beneficiaries who together determine how value manifests itself in the complex context of sports.

This should be carefully considered in the management of business processes. The planning and implementation of business practices, both in and through sport perspectives, requires special skills and knowledge on the part of company 
and sports managers. Understanding the special features of sports, customer insight, branding, and sponsorship are all essential skills for managers in the co-creative nature of value creation in the context of sports. According to Smith and Steward [25], management strategies that give no recognition to their special features will fail to deliver optimal outcomes.

\subsection{Research Limitations and Avenues for Further Research}

As with any study, there are some limitations that should be taken into consideration. In a literature review, there is always the challenge of research objectivity. To overcome this, a careful execution plan was carried out before the project started. Our review was limited to chosen databases and their publications. More research in value creation in sports management could be found in other research articles that were out of the scope of our research method. The literature review is exploratory and requires an empirical study to verify the relationships and interactions in value creation.

The articles under review for this study consist of publications in both management/marketing journals and sports journals. In this study, both disciplines are seen as equally important and informative for our question. However, management and marketing scholars presumably see the potential of the value creation in the nexus between business and sport through a different lens than sports scholars. Sport researchers might have a motive to promote their lessons, whereas management researchers may adopt a more critical stance towards brand creation, CSR, leadership, or strategic management lessons from sport. In future, it would be valuable to recognise which elements in sport are seen as contributory factors to management/marketing theory by sports scholars, and especially the extent to which they equate with the elements that management/marketing scholars value, and are therefore using in their own publications.

Our review of the existing research on value in sports management suggests a number of research ideas that could be pursued in future research. Firstly, there is a proliferation of literature on the topic of value creation in management. However, the concept of value in sports management has not been acknowledged this profoundly before. Thus, more research about the interaction between business and sport in value creation is called for in general. Secondly, future research could examine the potential of sport's value creation from the perspective of business managers. This direction of research would proffer new insights into the process of how business managers can enhance their value creation strategies. Thirdly, in this literature review we found that the concept of value rarely develops out of nowhere. Often the value was created in a process, where emotional or symbolical value was transferred into economic and functional value. An interesting line of research would be to investigate the antecedents and outcomes of this value transformation empirically.

\section{References}

[1] Forbes (2018) The World's Highest-Paid Athletes. Accessed 16 January 2018. 
https://www.forbes.com/athletes/\#5c16a39255ae

[2] BBC (2015) Premier League TV Rights: Sky and BT pay $£ 5.1$ bn for Live Games. http://www.bbc.co.uk/sport/0/football/31357409

[3] Agrawal, J. and Kamakura, W.A. (1995) The Economic Worth of Celebrity Endorsers: An Event Study Analysis. Journal of Marketing, 59, 56-62. https://doi.org/10.2307/1252119

[4] Miyazaki, A.D. and Morgan, A.G. (2001) Assessing Market Value of Event Sponsoring: Corporate Olympic Sponsorships. Journal of Advertising Research, 41, 9-15. https://doi.org/10.2501/JAR-41-1-9-15

[5] Reiser, M., Breuer, C. and Wicker, P. (2012) The Sponsorship Effect: Do Sport Sponsorship Announcements Impact the Firm Value of Sponsoring Firms? International Journal of Sport Finance, 7, 232-248.

[6] Cornwell, B.T., Roy, D.P. and Steinard, E.A. (2001) Exploring Managers' Perceptions of the Impact of Sponsorship on Brand Equity. Journal of Advertising, 30, 41-51. https://doi.org/10.1080/00913367.2001.10673636

[7] Statista. Global Sponsorship Spending from 2007 to 2016. https://www.statista.com/statistics/196864/global-sponsorship-spending-since-2007

[8] Walliser, B. (2003) An International Review of Sponsorship Research: Extension and Update. International Journal of Advertising, 22, 5-40.

https://doi.org/10.1080/02650487.2003.11072838

[9] Smith, A.C.T. and Westerbeek, H.M. (2007) Sport as a Vehicle for Deploying Corporate Social Responsibility. Journal of Corporate Citizenship, 25, 43-54. https://doi.org/10.9774/GLEAF.4700.2007.sp.00007

[10] Wolfe, R.A., Weick, K.-E., Usher, J.M., Terborg, J.R., Poppo, L., Murrell, A.J., Dukerich, J.M., Crown Core, D., Dickson, K.E. and Simmons Jourdan, J. (2005) Sport and Organizational Studies: Exploring Synergy. Journal of Management Inquiry, 14, 182-210. https://doi.org/10.1177/1056492605275245

[11] Burnes, B. and O’Donnell, H. (2011) What Business Leaders Learn from Sport? Sport, Business and Management: An International Journal, 1, 12-27.

[12] Crader, T.J. and Santomier, J. (2011) Imagination at Work and Play: A Case-Study Analysis of General Electric's Olympic Sponsorship. Sport, Business and Management: An International Journal, 1, 61-75. https://doi.org/10.1108/20426781111107171

[13] Stewart, B., Nicholson, M. and Smith, A.C.T. (2003) Sport Consumer Typologies: A Critical Review. Sport Marketing Quarterly, 12, 206-216.

[14] James, J.D. and Ross, S.D. (2004) Comparing sport Consumer Motivations across Multiple Sports. Sport Marketing Quarterly, 13, 17-25.

[15] Walters, G. and Tacon, R. (2010) Corporate Social Responsibility in Sport: Stakeholder Management in the UK Football Industry. Journal of Management \& Organization, 16, 566-586. https://doi.org/10.1017/S1833367200001942

[16] Uhrich, S., Koeningstorfer, J. and Groeppel-Klein, A. (2014) Leveraging Sponsorship with Corporate Social Responsibility. Journal of Business Research, 67, 2023 2029. https://doi.org/10.1016/j.jbusres.2013.10.008

[17] Woratschek, H., Horbel, C. and Popp, B. (2014) The Sport Value Framework-A New Fundamental Logic for Analysis in Sport Management. European Sport Management Quarterly, 14, 6-24. https://doi.org/10.1080/16184742.2013.865776

[18] Dionisio, P., Leal, C. and Moutinho, L. (2008) Fandom Affiliation and Tribal Beha- 
viour: A Sports Marketing Application. Qualitative Market Research, 11, 17-39. https://doi.org/10.1108/13522750810845531

[19] Cortsen, K. (2013) Annika Sörenstam-A Hybrid Personal Sports Brand. Sport, Business and Management: An International Journal, 3, 37-62. https://doi.org/10.1108/20426781311316898

[20] Eymard-Duvernay, F., Favereau, O., Orléan, A., Salais, R. and Thévenot. L. (2005) Pluralist Integration in Economic and Social Science: The Economy of Conventions. Post-Autistic Economics Review, 34, 22-40.

[21] Vargo, S.L. and Lusch, R.F. (2015) Institutions and Axioms: An Extension and Update of Service-Dominant Logic. Journal of the Academy of Marketing Science, 44, 5-23. https://doi.org/10.1007/s11747-015-0456-3

[22] Chalip, L. (2006) Toward a Distinctive Sport Management Discipline. Journal of Sport Management, 20, 1-21. https://doi.org/10.1123/jsm.20.1.1

[23] Foster, G., Greyser, S.A. and Walsh, B. (2006) The Business of Sports: Texts and Cases on Strategy and Management. Thomson, New York.

[24] Stewart, B. and Smith, A.C.T. (1999) The Special Features of Sport. Annals of Leisure Research, 2, 87-99. https://doi.org/10.1080/11745398.1999.10600874

[25] Smith, A.C.T. and Stewart, B. (2010) The Special Features of Sport: A Critical Revisit. Sport Management Review, 13, 1-13. https://doi.org/10.1016/j.smr.2009.07.002

[26] Vargo, S.L. and Lusch, R.F. (2004) Evolving to a New Dominant Logic for Marketing. Journal of Marketing, 68, 1-17. https://doi.org/10.1509/jmkg.68.1.1.24036

[27] Galvagno, M. and Dalli, D. (2014) Theory of Value Co-Creation: A Systematic Literature Review. Managing Service Quality, 24, 643-683. https://doi.org/10.1108/MSQ-09-2013-0187

[28] Costa, C.A. (2005) The Status and Future of Sport Management: Adelphi Study. Journal of Sport Management, 19, 119-142. https://doi.org/10.1123/jsm.19.2.117

[29] Cunningham, G.B. (2013) Theory and Theory Development in Sport Management. Sport Management Review, 16, 1-4. https://doi.org/10.1016/j.smr.2012.01.006

[30] Tranfield, D., Denyer, D. and Smart, P. (2003) Towards a Methodology for Developing Evidence-Informed Management Knowledge by Means of Systematic Review. British Journal of Management, 14, 207-222. https://doi.org/10.1111/1467-8551.00375

[31] Petticrew, M. and Roberts, H. (2006) Systematic Reviews in the Social Sciences: A Practical Guide. Blackwell Publishing, Malden.

[32] Amit, R. and Zott, C. (2001) Value Creation in E-Business. Strategic Management Journal, 22, 493-552. https://doi.org/10.1002/smj.187

[33] Lee, C., Lee, K. and Pennings, J.M. (2001) Internal Capabilities, External Networks, and Performance: A Study of Technology-Based Ventures. Strategic Management Journal, 22, 615-640.

[34] Johanson, J. and Mattson, L.-G. (1987) Inter-Organizational Relations in Industrial Systems: A Network Approach Compared with the Transaction Cost Approach. International Studies of Management and Organization, 17, 34-48.

[35] Vargo, S.L., Maglio, P.P. and Archpru Akaka, M. (2008) On Value and Value Co-Creation: A Service Systems and Service Logic Perspective. European Management Journal, 26, 149-152. https://doi.org/10.1016/j.emj.2008.04.003

[36] Gummesson, E. (2008) Extending the Service-Dominant Logic: From Customer Centricity to Balanced Centricity. Journal of the Academy of Marketing Science, 36, 
15-17. https://doi.org/10.1007/s11747-007-0065-X

[37] Delaney, L. and Fahey, T. (2005) Social and Economic Value of Sport in Ireland. Economic and Social Research Institute.

[38] Shilbury, D., Westerbeek, H.M., Quick, S. and Funk, D. (2009) Strategic Sport Marketing. Allen \& Unwin, Sydney.

[39] Pyun, D.Y., Kwon, H., Chon, T.J. and Han, J.W. (2012) How Does Advertising through Sport Work? Evidence from College Students in Singapore. European Sport Management Quarterly, 12, 43-63. https://doi.org/10.1080/16184742.2011.637172

[40] Sheth, J.N., Newman, B.I. and Gross, B.L. (1991) Why We Buy What We Buy: A Theory of Consumption Values. Journal of Business Research, 22, 159-170. https://doi.org/10.1016/0148-2963(91)90050-8

[41] Rintamäki, T., Kuusela, H. and Mitronen, L. (2007) Identifying Competitive Customer Value Propositions in Retailing. Managing Service Quality, 17, 621-634. https://doi.org/10.1108/09604520710834975

[42] Huselid, M.A. (1995) The Impact of Human Resource Management Practices on Turnover, Productivity, and Corporate Financial Performance. Academy of Management Journal, 38, 635-672.

[43] Patterson, P.G. and Spreng, R.A. (1997) Modeling the Relationship between Perceived Value, Satisfaction and Repurchase Intentions in a Business-to-Business, Services Context: An Empirical Examination. The International Journal of Service Industry Management, 8, 415-432. https://doi.org/10.1108/09564239710189835

[44] Kim, H.-B., Kim, W.G. and An, J.A. (2003) The Effect of Consumer-Based Brand Equity on Firms' Financial Performance. Journal of Consumer Marketing, 20, 335-352. https://doi.org/10.1108/07363760310483694

[45] Greenhalgh, T. and Peacock, R. (2005) Effectiveness and Efficiency of Search Methods in Systematic Reviews of Complex Evidence: Audit of Primary Sources. British Medical Journal, 331, 1064-1065. https://doi.org/10.1136/bmj.38636.593461.68

[46] Glaser, B.G. and Strauss, A.L. (1967) The Discovery of Grounded Theory: Strategies for Qualitative Research. Aldine Publishing Company, Chicago.

[47] Wiggins, D. (1997) Incommensurability: Four Proposals. In: Chang, R. Ed., Incommensurability, Incomparability, and Practical Reason, Harvard University Press, Cambridge, 52-66.

[48] Clark, J.M., Cornwell, B.T. and Pruitt, S.W. (2009) The Impact of Title Event Sponsorship Announcements on Shareholder Wealth. Marketing Letters, 20, 169-182. https://doi.org/10.1007/s11002-008-9064-Z

[49] Donlan, L. (2014) An Empirical Assessment of Factors Affecting the Brand-Building Effectiveness of Sponsorship. Sport, Business and Management 4:1, 6-25. https://doi.org/10.1108/SBM-09-2011-0075

[50] Dix, S., Phau, I. and Pougnet, S. (2010) Bend It Like Beckham: The Influence of Sports Celebrities on Young Adult Consumers. Young Consumers, 11, 36-46. https://doi.org/10.1108/17473611011025993

[51] Kwak, D.H. and Kang, J.-H. (2009) Symbolic Purchase in Sport: The Roles of Self-Image Congruence and Perceived Quality. Management Decision, 47, 85-99. https://doi.org/10.1108/00251740910929713

[52] DeSarbo, W.S. and Madrigal, R. (2011) Examining the Behavioral Manifestations of fan Avidity in Sports Marketing. Journal of Modelling in Management, 6, 79-99. https://doi.org/10.1108/17465661111112511 
[53] Richelieu, A. and Korai, B. (2012) Identity and Sport: Young French Canadians and the Montreal Canadiens Hockey Club. Sport, Business and Management: An International Journal, 2, 127-136. https://doi.org/10.1108/20426781211244024

[54] Abosag, I., Roper, S. and Hind, D. (2012) Examining the Relationship between Brand Emotion and Brand Extension among Supporters of Professional Football Clubs. European Journal of Marketing, 46, 1233-1251. https://doi.org/10.1108/03090561211247810

[55] Lee, S.P., Cornwell, B.T. and Babial, K. (2012) Developing an Instrument to Measure the Social Impact of Sport: Social Capital, Collective Identities, Health Literacy, Well-Being and Human Capital. Journal of Sports Management, 27, 24-42. https://doi.org/10.1123/jsm.27.1.24

[56] Wood, L. (2000) Brands and Brand Equity: Definition and Management. Management Decision, 38, 662-669. https://doi.org/10.1108/00251740010379100

[57] Bauer, H.H., Sauer, N.E. and Schmitt, P. (2005) Customer-Based Brand Equity in the Team Sport Industry. European Journal of Marketing, 39, 496-513. https://doi.org/10.1108/03090560510590683

[58] Guenzi, P. and Nocco, M. (2006) The Launch of New Brands by Professional Soccer Teams: The Case of U.S. Lecce-Salento 12. International Journal of Sports Marketing \& Sponsorship, 7, 99-114. https://doi.org/10.1108/IJSMS-07-03-2006-B010

[59] Yoshida, M. and Gordon, B. (2012) Who Is More Influenced by Customer Equity Drivers? A Moderator Analysis in a Professional Soccer Context. Sport Management Review, 15, 389-403.

https://doi.org/10.1016/j.smr.2012.03.001

[60] Gwinner, K. and Bennett, G. (2008) The Impact of Brand Cohesiveness and Sport Identification on Brand Fit in a Sponsorship Context. Journal of Sport Management, 22, 410-426. https://doi.org/10.1123/jsm.22.4.410

[61] Herrmann, J.-L., Corneille, O., Derbaix, C., Kacha, M. and Walliser, B. (2014) Implicit Sponsorship Effects for A Prominent Brand. European Journal of Marketing, 48, 785-804. https://doi.org/10.1108/EJM-11-2011-0624

[62] Carrilat, F.A. and d'Astous, A. (2012) The Sponsorship-Advertising Interface: Is Less Better for Sport? European Journal of Marketing, 46, 562-574. https://doi.org/10.1108/03090561211202611

[63] Braunsten-Minkove, J.R., Zhang, J.J. and Trail, G.T. (2011) Athlete Endorser Effectiveness: Model Development and Analysis. Sport, Business and Management: An International Journal, 1, 93-114. https://doi.org/10.1108/20426781111107199

[64] Lacey, R. and Close, A.G. (2013) How Fit Connects Service Brand Sponsors with Consumers' Passions for Sponsored Events. International Journal of Sport Marketing and Sponsorship, 14, 212-228. https://doi.org/10.1108/IJSMS-14-03-2013-B005

[65] Thomas, R.J. (2014) An Evaluation of the Effectiveness of Rugby Event Sponsorship: A Study of Dove Men+Care and the Welsh Rugby Union. Journal of Product \& Brand Management, 23, 304-321. https://doi.org/10.1108/JPBM-03-2014-0533

[66] Doyle, J.P., Pentecost, R.D. and Funk, D.C. (2014) The Effect of Familiarity on Associated Sponsor and Event Brand Attitudes Following Negative Celebrity Endorser Publicity. Sport Management Review, 17, 310-323. https://doi.org/10.1016/j.smr.2013.10.003

[67] Farrelly, F. (2010) Not Playing the Game: Why Sport Sponsorship Relationships Break Down. Journal of Sport Management, 24, 319-337. https://doi.org/10.1123/jsm.24.3.319 
[68] Anagnostopoulos, C. and Shilbury, D. (2013) Implementing Corporate Social Responsibility on English Football. Sport, Business and Management: An International Journal, 3, 268-284. https://doi.org/10.1108/SBM-05-2013-0009

[69] Blumrodt, J., Desbordes, M. and Bodin, D. (2013) Professional Football Clubs and Corporate Social Responsibility. Sport, Business and Management: An International Journal, 3, 205-225. https://doi.org/10.1108/SBM-04-2011-0050

[70] Porter, M.E. and Kramer, M.R. (2006) The Big Idea: Creating Shared Value. Harvard Business Review, 89, 62-77.

[71] Mullen, J. (1997) Performance-Based Corporate Philanthropy: How "Giving Smart" Can Further Corporate Goals. Public Relations Quarterly, 42, 42-49.

[72] Dean, D.H. (2003) Association the Cooperation with the Charitable Event through Sponsorship: Measuring the Effects on Corporate-Community Relations. Journal of Advertising, 31, 77-88. https://doi.org/10.1080/00913367.2002.10673687

[73] Filizöz, B. and Fisne, M. (2011) Corporate Social Responsibility: A Study of Striking Corporate Social Responsibility Practices in Sport Management. Procedia Social and Behavioral Sciences, 24, 1405-1417. https://doi.org/10.1016/j.sbspro.2011.09.062

[74] Parent, M.M. and Foreman, P.O. (2007) Organizational Image and Identity Management in Large-Scale Sporting Events. Journal of Sport Management, 21, 15-40. https://doi.org/10.1123/jsm.21.1.15

[75] Inoue, Y., Kent, A. and Lee, S. (2011) CSR and the Bottom Line: Analyzing the Link between CSR and Financial Performance for Professional Teams. Journal of Sport Management, 25, 531-549. https://doi.org/10.1123/jsm.25.6.531

[76] Bingham, T. and Walters, G. (2013) Financial Sustainability within UK Charities: Community Sport Trust Internal and Corporate Social Responsibility Partnerships. VOLUNTAS: International Journal of Voluntary and Nonprofit Organizations, 24, 606-629. https://doi.org/10.1007/s11266-012-9275-Z

[77] Li, M., Hofacre, S. and Mahony, D. (2001) Economics of Sport. Fitness Information Technology, Morgantown.

[78] Borland, J. (2006) The Production of Professional Team Sports. In: Adreff, W. and Szymanski, S., Eds., Handbook on the Economics of Sport, Edward Elgar, Cheltenham, 22-26.

[79] Ferrand, A., Chappelet, J.-L. and Seguin, B. (2012) Olympic Marketing. Routledge, London.

[80] Shilbury, D. (2012) Competition: The Heart and Soul of Sport Management. Journal of Sport Management, 26, 1-10. https://doi.org/10.1123/jsm.26.1.1

[81] Contractor, F.J. and Lorange, P. (1988) Cooperative Strategies in International Business. Lexington Books, Boston.

[82] Hakansson, H. and Snehota, I. (1995) Developing Relationship in Business Networks. Routledge, London.

[83] Shilbury, D. (2000) Considering Future Sport Delivery Systems. Sport Management Review, 3, 199-221. https://doi.org/10.1016/S1441-3523(00)70086-6

[84] Budzinski, O. and Satzer, J. (2011) Sport Business and Multisided Markets: Towards a New Analytical Framework? Sport, Business and Management: An International Journal, 1, 124-137. https://doi.org/10.1108/20426781111146736

[85] Gerke, A., Desbordes, M. and Dickson, G. (2015) Towards a Sport Cluster Model: The Ocean Racing Cluster in Brittany. European Sport Management Quarterly, 15, 343-363. http://www.tandfonline.com/doi/full/10.1080/16184742.2015.1019535 
[86] Wäsche, H. (2015) Interorganizational Cooperation in Sport Tourism: A Social Network Analysis. Sport Management Review, 18, 542-554. https://doi.org/10.1016/j.smr.2015.01.003

[87] Bengtsson, M. and Kock, S. (2000) "Coopetition" in Business Networks-To Cooperate and Compete Simultaneously. Industrial Marketing Management, 29, 411-426. https://doi.org/10.1016/S0019-8501(99)00067-X

[88] Lorgnier, N. and Su, C.-H. (2014) Considering Coopetition Strategies in Sport Tourism Networks: A Look at the Nonprofit Nautical Sports Clubs on the Northern Coast of France. European Sport Management Quarterly, 14, 87-109. https://doi.org/10.1080/16184742.2013.876436

[89] Benijts, T., Lagae, W. and Vanclooster, B. (2011) The Influence of Sport Leagues on the Business-to-Business Marketing of Teams: The Case of Professional Road Cycling. Journal of Business \& Industrial Marketing, 26, 602-613. https://doi.org/10.1108/08858621111179877

[90] Smith, A. (2010) The Development of "Sports-City" Zones and Their Potential as Tourism Resources for Urban Areas. European Planning Studies, 18, 385-410. https://doi.org/10.1080/09654310903497702

[91] Olkkonen, R. (2001) The Network Approach to International Sport Sponsorship Arrangement. Journal of Business \& Industrial Marketing, 16, 309-329. https://doi.org/10.1108/EUM0000000005503

[92] Pichot, L., Pierre, L. and Burlot, F. (2009) Management Practices in Companies through Sport. Management Decision, 47, 137-150.

https://doi.org/10.1108/00251740910929759

[93] Khan, A., Stanton, J. and Rahman, S. (2013) Employees' Attitudes towards the Sponsorship Activity of Their Employer and Links to Their Organisational Citizenship Behaviours. International Journal of Sports Marketing \& Sponsorship, 14, 279-330. https://doi.org/10.1108/IJSMS-14-04-2013-B003

[94] Day, D.V., Gordon, S. and Fink, C. (2012) The Sporting Life: Exploring Organizations through the Lens of Sport. The Academy of Management Annals, 6, 397-433. https://doi.org/10.1080/19416520.2012.678697

[95] Kerwin, S. and Bopp, T. (2014) Exploring Cognitive Restructuring: A Multi-Foci Leadership Perspective. Sport Management Review, 17, 277-291. https://doi.org/10.1016/j.smr.2013.11.005

[96] Madichie, N. (2009) Management Implications of Foreign Players in the English Premiership League Football. Management Decision, 47, 24-50. https://doi.org/10.1108/00251740910929687

[97] Carlson, B.D., Donavan, T.D. and Cumiskey, K.J. (2009) Consumer-Brand Relationships in Sport: Brand Personality and Identification. International Journal of Retail \& Distribution Management, 37, 370-384. https://doi.org/10.1108/09590550910948592

[98] Pritchard, M.P., Stinson, J.L. and Patton, E. (2010) Affinity and Affiliation: The Dual-Carriage Way to Team Identification. Sport Marketing Quarterly, 19, 67-77.

[99] Hedlund, D.P. (2014) Creating Value through Membership and Participation in Sport Fan Consumption Communities. European Sport Management Quarterly, 14, 50-71. https://doi.org/10.1080/16184742.2013.865775

[100] Close, A.G. and Lacey, R. (2013) Fit Matters? Asymmetrical Impact for Effectiveness on Sponsors and Event Marketers. Sport Marketing Quarterly, 22, 71-82.

[101] Tsiotsou, R. (2012) Developing a Scale for Measuring the Personality of Sport 
Teams. Journal of Services Marketing, 26, 238-252. https://doi.org/10.1108/08876041211237541

[102] Tsiotsou, R. (2013) Sport Team Loyalty: Integrating Relationship Marketing and a Hierarchy of Effects. Journal of Services Marketing, 27, 458-471. https://doi.org/10.1108/JSM-01-2012-0002

[103] Tajfel, H. (1978) Social Categorization, Social Identity and Social Comparison. In: Taifel, H., Ed., Differentiation between Social Groups, Academic Press, London, 61-76.

[104] Tajfel, H. (1981) Human Groups and Social Categories. Cambridge University Press, Cambridge.

[105] Bhattacharya, C.B., Rao, H. and Glynn, M.A. (1995) Understanding the Bond of Identification: An Investigation of Its Correlates Among Art Museum Members. Journal of Marketing, 59, 46-57. https://doi.org/10.2307/1252327

[106] Lichtenstein, D.R., Drumwright, M.E. and Braig, B.M. (2004) The Effect of Corporate Social Responsibility on Consumer Donations to Corporate-Supported Nonprofits. Journal of Marketing, 68, 16-32. https://doi.org/10.1509/jmkg.68.4.16.42726

[107] Sutton, W.A., McDonald, M.A., Milne, G.R. and Cimperman, J. (1997) Creating and Fostering Fan Identification in Professional Sports. Sport Marketing Quarterly, 6, 15-22.

[108] McDonald, M.A. and Milne, G.R. (1997) A Conceptual Framework for evaluating Marketing Relationships in Professional Sport Franchises. Sport Marketing Quarterly, 6, 27-32.

[109] Harada, M. and Hirotaka, M. (1999) The Influence of New Team Entry upon Brand Switching in the J-League. Sport Marketing Quarterly, 8, 21-30.

[110] Funk, D.C. and Pritchard, M.P. (2006) Sport Publicity: Commitment's Moderation of Message Effects. Journal of Business Research, 59, 613-621. https://doi.org/10.1016/j.jbusres.2005.10.010

[111] Sirgy, J.M. (1982) Self-Concept in Consumer Behavior: A Critical Review. Journal of Consumer Research, 9, 287-300. https://doi.org/10.1086/208924

[112] Fitzmaurice, J. (2005) Incorporating Consumers' Motivations into the Theory of Reasoned Action. Psychology and Marketing, 22, 911-929. https://doi.org/10.1002/mar.20090

[113] Govers, P.C.M. and Schoormans, J.P.L. (2005) Product Personality and Its Influence on Consumer Preference. Journal of Consumer Marketing, 22, 189-197. https://doi.org/10.1108/07363760510605308

[114] Heath, A.P. and Scott, D. (1998) The Self-Concept and Image Congruence Hypothesis: An Empirical Evaluation in the Motor Vehicle Market. European Journal of Marketing, 32, 1110-1123. https://doi.org/10.1108/03090569810243749

[115] Hogg, M.K., Cox, A.J. and Keeling, K. (2000) The Impact of Self-Monitoring on Image Congruence and Product/Brand Evaluation. European Journal of Marketing, 34, 641-666. https://doi.org/10.1108/03090560010321974

[116] Kressmann, F., Sirgy, J.M., Herrmann, A., Huber, F., Huber, S. and Lee, D.-J. (2006) Direct and Indirect Effects of Self-Image Congruence on Brand Loyalty. Journal of Business Research, 59, 955-964. https://doi.org/10.1016/j.jbusres.2006.06.001

[117] Sirgy, J.M. and Samli, C.A. (1985) A Path Analytic Model of Store Loyalty Involving Self-Concept, Store Image, Geographic Loyalty, and Socioeconomic Status. Journal of the Academy of Marketing Science, 13, 265-271.

https://doi.org/10.1007/BF02729950 
[118] Graeff, T.R. (1996) Image Congruence Effects on Product Evaluations: The Role of Self-Monitoring and Public/Private Consumption. Psychology and Marketing, 13, 481-499. https://doi.org/10.1002/(SICI)1520-6793(199608)13:5<481::AID-MAR3>3.0.CO;2-5

[119] Sánchez-Fernández, R. and Iniesta-Bonillo, Á. (2007) The Concept of Perceived Value: A Systematic Review of the Research. Marketing Theory, 7, 427-451. https://doi.org/10.1177/1470593107083165

[120] Wong, L., Bliese, P. and McGurk, D. (2003) Military Leadership: A Context Specific Review. The Leadership Quarterly, 14, 657-692. https://doi.org/10.1016/j.leaqua.2003.08.001

[121] Parush, T. and Koivunen, N. (2014) Paradoxes, Double Binds, and the Construction of "Creative" Managerial Selves in Art-Based Leadership Development. Scandinavian Journal of Management, 30, 104-113.

[122] Gilmartin, M.J. and D’Aunno, T.A. (2007) Leadership Research in Healthcare: A Review and Roadmap. The Academy of Management Annals, 1, 387-438. https://doi.org/10.1080/078559813

[123] Tracey, P. (2012) Religion and Organization: A Critical Review of Current Trends and Future Directions. The Academy of Management Annals, 6, 87-134. https://doi.org/10.1080/19416520.2012.660761

[124] Boltanski, P.C. and Thévenot, L. (2006) On Justification. Economies of Worth. Princeton University Press, New York.

[125] Brennan, G. and Pettit, P. (2006) The Economy of Esteem. Oxford University Press, Oxford.

[126] Chadwick, S. (2009) From Outside Lane to Inside Track: Sport Management Research in the Twenty-First Century. Management Decision, 47, 191-203. https://doi.org/10.1108/00251740910929786

[127] Shwartz, S.H. (1992) Universals in the Content and Structure of Values: Theoretical Advances and Empirical Tests in 20 Countries. Advances in Experimental Social Psychology, 25, 1-65. https://doi.org/10.1016/S0065-2601(08)60281-6

[128] Smith, A.C.T., Stavros, C. and Westberg, K. (2017) Brand Fans. Lessons from the World's Greatest Sporting Brands. Palgrave McMillan, Melbourne.

[129] Liden, R.C. and Antonakis, J. (2009) Considering Context in Psychological Leadership Research. Human Relations, 62, 1587-1605. https://doi.org/10.1177/0018726709346374

[130] Porter, L.W. and McLaughlin, G.B. (2006) Leadership and the Organizational Context: Like the Weather? The Leadership Quarterly, 17, 559-576. https://doi.org/10.1016/j.leaqua.2006.10.002

[131] Sheth, H. and Babiak, K.B. (2010) Beyond the Game: Perceptions and Priorities of Corporate Responsibility in the Sport Industry. Journal of Business Ethics, 91, 433-450. https://doi.org/10.1007/s10551-009-0094-0

[132] Blumrodt, J., Bryson, D. and Flanagan, J. (2012) European Football Teams's CSR Engagement Impacts on Customer-Based Brand Equity. Journal of Consumer Marketing, 29, 482-492. https://doi.org/10.1108/07363761211274992

[133] Hu, J., Lee, C.H., Wong, H.R. and Kao, T. (2012) Understanding Corporate Irresponsibility on Sport Organizations. International Business Research, 5, 46-58. https://doi.org/10.5539/ibr.v5n12p46 